\title{
10. A VILLAMOS ENERGIA HASZNOSÍTÁSÁNAK KEZDETEI
}

\section{FEJEZETEK CSÍKSZEREDA VILLAMOSÍTÁSÁNAK TÖRTÉNETÉBŐL}

„1911. február 11-ike jelentős dátum Csíkszereda kultúrtörténetében, mert e napon adatott át a Ganz-féle városi villamosmú rendeltetésének. $A$ város közönsége jóleső örömmel gyönyörködött a Budapestre beillő fényárban, mely az egész várost elborította" - így üdvözölte a villanyfényt 1911 februárjában a Csíki Lapok újságírója, aki gyors összehasonlítást is tett más székelyföldi városokkal, megjegyezve, hogy „A leghatározottabban állíthatjuk, hogy a szomszéd Sepsiszentgyörgy, Székelyudvarhely és Gyergyószentmiklós városok villanyvilágítását túlszárnyaltuk, mi föleg abban leli magyarázatát, hogy a villanyoszlopok az utcákon alig 30-35 méternyi távolságra nem 16-20-as, hanem 40-es körtékkel vannak ellátva mi pazar világításnak mondható." (Villanyvilágítás 1911. 2.) Nem volt véletlen a korabeli újságíró megjegyzése, így próbálta „menteni a mundér becsületét”, vagyis azt a tényt, hogy Csíkszereda jócskán lemaradt a villamosítási sorban, hiszen az akkor még nagyközségnek számító Gyergyószentmiklós nyolc évvel, Székelyudvarhely pedig három évvel előzte meg.

Jelen írásban elsősorban a korabeli sajtó és néhány levéltári dokumentum alapján foglaltuk össze Csíkszereda villamosításának első évtizedeit, emellett felhasználtunk adatokat Vofkori Györgynek a csíkszeredai villany- telepre vonatkozó írásából (Vofkori György 2007. 270-274.), de a kutatás korántsem teljes.

\section{A kezdetek}

Tivai Nagy Imre (1849-1931) jeles csíkszeredai közíró leírásából tudjuk, hogy tűz világánál, faggyú- vagy szurokmécses mellett, előkelőbb helyeken faggyúgyertya fényénél időztek, kézimunkáztak sötétedés után eleink, amíg 1870 körül Csíkban is megjelent a petróleumvilágítás. Volt időszak, amikor Csíkszeredában „petróleumlámpával világítottak az utcán is. Oszlopok voltak felállítva, amelyeknek tetején egy üvegfalú bádog doboz-szekrényke volt, benne a lámpa. Panni János városi alkalmazott minden reggel egy kis lajtorján felment sorban minden oszlop$r a$, levette a lámpát, megtörölgette az üveget, petróleumot töltött a lámpába és visszatette. Estefelé újra bejárta a várost, felment létrán a lámpafára, és kénköves gyufával, amelyet a harisnya fenekén gyújtott meg, meggyújtotta a lámpát." (Gál József 1970).

Ez viszont nem jelenti azt, hogy 1911 előtt Csíkszeredában meg sem fordult villanyszerelő, vagy nem hallottak a villamosságról. Az egyik első ajánlatot a város utcáinak és nyilvános tereinek villamos világítására 1897ben nyújtotta be Csíkszereda tanácsához egy vállalkozó (Villamos világitás Csik-Szeredában 1897.). Ugyancsak ő tett ajánlatot 
„Az esténként végzett munka tűzvilágnál, faggyú vagy szurok mécses mellett, avagy igen előkelő helyen faggyúgyertya világánál folyt, mert a petróleum világítás csak a hatvanas évek végén, inkább a hetvenes évek elején jött használatba. A lábakon álló csempés alatt a hasábfák szabad tűzön égtek, mely elég világosságot árasztott a tűzhely előtt folyó apró munkákra. Még a varrottasok is ezen világítás mellett készültek, miközben a góc lábánál avagy a sód mellett ülő egyik családtag állandóan el volt foglalva a tűz szításával. A cserépfáján vagy csempés oldalán álló, vékonyra hasogatott hosszú fenyőfa szálkák pipagyújtásra, vagy a szoba valamely zugában, a kamarában vagy pincében való keresgélés céljára gyújtattak és mindég készen állottak. Ugyanezen célt szolgálta a szurok-mécses, mely egy törött fazékba állított és beszurkozott csepűmadzagból állott s meggyújtott vége nagy lánggal és még nagyobb büdös füsttel égett. A gyertyaöntő bádog forma minden háznál készen állott, melyben vendéglátás alkalmával a gyűjtögetett juh- vagy marha faggyúból két-három szál gyertyát öntöttek. Ez volt a legelőkelőbb világítás. Stearin- vagy paraffingyertya csak a templomi luszterekben égett. A faggyúgyertya nélkülözhetetlen társa volt a koppantó, mellyel a gyakran megnőtt gyertyahamvat kellett levágni. Az ezzel való ügyes bánás majdnem az etikette szabályait igényelte, miért a házi férjhezadandó leány mindig reszkető kézzel nyúlt a koppantóhoz. A gyertya hamvához kézzel nyúlni a legilletlenebb cselekedet számba ment. Hogy milyen volt a koppantó, azt meg lehet látni majdan a csíkmegyei múzeumban, mert leírni bajos; Iegfennebb annyit jegyzek fel róla, hogy előkelő úri házaknál ezüstből volt és hosszúkás, kis ezüst tálcán állott, a több ágú ezüst gyertyatartó mellett." (Tivai Nagy Imre 1996. 73-74.) a „magánosok” részére a villany házakba és szobákba való bevezetésére. Ugyanebben az évben Herczka Gyula is ajánlotta szolgáltatásait (Herczka Gyula 1897.). Az ő neve azért érdekes, mert később Csíkszeredában telepedett le, és minden valószínűség szerint neki volt Csíkszeredában az első elektrotechnikai és műszaki szaküzlete, amely már jóval a villanyvilágítás bevezetése előtt működött: a korabeli sajtó híradásai szerint 1900-ban nyitotta meg (Elektrotechnikai és müszaki üzlet 1900), reklámjaival pedig több mint egy évtizedig találkozhatunk a lapok hasábjain (Herczka Gyula 1909). Szintén Herczka Gyulához kötődik egy különleges találmány is, a rádiumvilágítás, amelyről 1908-ban azt írta az újság, hogy „a budapesti m. kir. József müegyetem által engedélyeztetett, szabadalmaztatott és törvényileg védve lett” és „az összes eddigi világításokat végleg ki fogja szoritani” (Új világitás 1908).

\section{VILLAMOS}

világitás, távbeszélés ès távirdaberendezésekre, valamint e szukmába vágó egyéb munkálatok és javitásokra helyben és vidéken ajánlkozik tisztelettel alulirt.

Költségvetésekkel, valamint bővebb telvilágositásokkal ingyen szolgálok.

\section{1-ig tart. \\ Itteni tartózkodásom 1898 január \\ 2-3 \\ Herczka Gyula.}

- Fektrotechnikai è mūgzaki üzlet. Herczkn (jyula cxikszrered ij lakos n Fried.

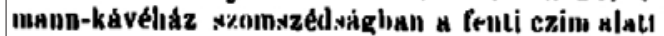
Azlotel oyil, s már moylai.til kezdve elvallanl vilIanyvilagitani, tolefon, távirıla és villamlıáriló bireudezésoket, Álalnkitavokat. jnvithsukat es mindennena nikkejezéseket Közveliti sxivallyak, tüzlocskerdok, löngyug. czement An vascrövek megrendelését, Cirammofonuk, fonngrafok, orvosi ha mindentele maszerak êt trknikni czikkek

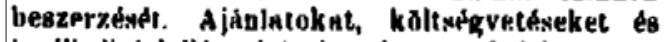
levélbrli lelvilágurilakokat ingyen es bermentve hénzsegggel ad.

1. kép. Herczka Gyula reklámai 
1901-ben arról olvashatunk, hogy közelebbről Gyergyószentmiklóson lesz villanyvilágítás, Csík vármegyében elsőként (Villamos világitás 1901).

„Villámos világítás Csik-Szeredában. Alig hogy megindult nálunk a vasut, a modern technikának már is egy másik vivmánya is kopogtat ajtóinkon. Ugy tudjuk, hogy a városhoz ajánlat tétetett a város utczáinak, nyilvános tereinek villamos világitására és a munkaátviteli villamos vezetésre szolgáló sodronyok lerakására. Az utczai közvilágitás egyelőre 16 gyertyafényü izzólámpával eszközöltetnék egy meghatározandó átalány összegért, mig a magánosok a házakba és szobákba való bevezetés esetén egy16 gyertyafényü izzólámpáért óránkint 2 krt, 10 gyertyafényüért 1,32 krt és 5 gyertyafényüért 0,66 krt vagyis fél krajczárt fizetnének. Ezenkivül azonban a magánosok a fogyasztás mérvéhez képest engedményben is részesülnének, nevezetesen az összes berendezett lámpáknak évi 600 órán át való üzembe vétele esetén $5 \%$-ot. 1000 óránál $10 \%$-ot, 2000 óránál $20 \%$-ot és 3000 óránál $30 \%$-ot. Az ajánlat szerint a városnak jogában áll a villamvilágitási üzemet 25 év múlva becsáron, 30 év múlva becsáron alól 5\% engedménynyel, 40 év múlva becsáron alól $15 \%$ engedménynyel, 50 év mulva becsáron alól 30\% engedménynyel mindenkor 2 évi felmondás kikötése mellett megváltani. Az érték meghatározásánál az anyagok értéke mintegy üzemben levő telep alkatrésze fog megbecsültetni. 70 év lejártával az egész áramfejlesztő telep az összes nyilvános vezetékkel és egyéb tartozékkal együtt ingyen fog a város tulajdonába bocsáttatni. Ezek szerint az első lépés, az ajánlat meg van téve, most jön a második lépés, a tanulmányozás." (Csíki lapok, 1897. április 21.)
„Villamos világitás. Csikmegyében is lesz már közelebbről villamos világítás. Az itteni viszonyokkal nem ismerős emberek bizonyára azt hiszik, hogy ezen czélszerü ujitást Csíkszeredában, a vármegye központján fogják létesíteni. Pedig, de hogy; ilyen kérdésekkel Csíkszeredában nem igen foglalkoznak, hanem igen is Gyergyó-Szentmiklóson, melynek életre való elöljárósága igyekszik haladni, a korral s nem zárkózik el még a nagyobb anyagi áldozatoktól sem, ha olyan dolgot kell létesíteni, mely ugy a községnek, mint a község polgárainak elönyére válik. Gyergyó-Szentmiklósnak már a közel jövőben villamos világitása lesz; erre mutat az, hogy az előmunkálatokat vezető Márk Etele a mult héten megkészítette a villamos világítás hálózatának térképét." (Csíki lapok, 1901. október 9.)

1902-ben báró Bánffy János folyamadott engedélyért villanyfejlesztő telep létesítésért a Maroson.

1904-ben szinte irigykedve ír a Csíki Lapok arról, hogy míg Csíkszeredában az utcai lámpákat sem gyújtják meg éjszakára, addig Székelyudvarhely képviselőtestülete már a villany bevezetéséről tárgyal. „Boldog város, hol éjjel is nappali fényesség lesz, bár nekünk állandóan egy pislákoló mécses jutna!" (Villámvilágitás és egyiptomi sötétség 1904)

1904-ben Keller J. budapesti vállalkozó intézett felhívást a lakossághoz az aerogéngáz-világítás bevezetése ügyében - ezt a világítási megoldást rendelte meg a vármegye az akkor épülő Vigadó részére is (Csíkszereda világitása 1904). Az elképzelés vitát kavart, a lapokban érvek és ellenérvek ütköztek: míg a Csíkszereda címú lap az aerogéngáz-világítást támogatta (Csíkszereda világitása 1904), addig kezdetben a Csíki Lapok úgy vélte, hogy 
„Ha már munkát végzünk, végezzünk egész munkát s várjunk jobb napokra. Kis városok is a villámra rendezkednek be s azt hisszük, az Olt vizi erejének s esetleg egy uj ipari telepnek a felállitása módot nyujthat, már a közelben a kérdés végleges és szerencsés megoldására." (Haladunk 1904) Később a Csíki Lapok is egy átmeneti időszakra elfogadhatónak tartotta volna az aerogén világítás bevezetését (Aerogén-gázvilágitás 1904).

A csíkszeredai villany ügye a továbbiakban is számtalanszor napirenden szerepelt, mígnem 1909. április 14-én úgy tünt, hogy dr. Ujfalusi Jenő polgármester megvalósíthatja a „nagy reformot”, és a város kiírja a pályázatot a villanyvilágítás bevezetésére (Villanyvilágitás városunkban 1909). Ám a konkrét megvalósítás is számos akadályba ütközött, és további két évre volt szükség, hogy valóban kigyúljon a fény.
„Villanyvilágitás városunkban. Városunk agilis polgármestere nagy reformot valósit meg. Évek óta fáradozik, hogy a meg nem felelő világitást villanynyal cserélje fel. Őszintén szólva kétkedve néztünk fáradozásai elé, ismerve városunk szerény anyagi viszonyait. Amint azonban most értesülünk, az eszme testet ölt s már a közel jövőben megvalósulást nyer. A pályázatot közelebbről kihirdetik, mert a szükséges előfeltételek már biztosítva vannak." (Csíki Lapok, 1909. ápr. 14.)

\section{A megvalósítás}

„A várva várt villanyvilágítás teljesen a bizonytalanság kátyújába jutott" - írta a Csíki Lapokban 1911 januárjában „egy városi polgár". ,Legjobb értesüléseink szerint a Ganz-féle társaság épitési vezetősége összes munkálataival egészen készen van és a villanykörték akár ma is kigyúlhatnának, ha a posta továbbra is nem kísérletezne. Arról van ugyanis szó,

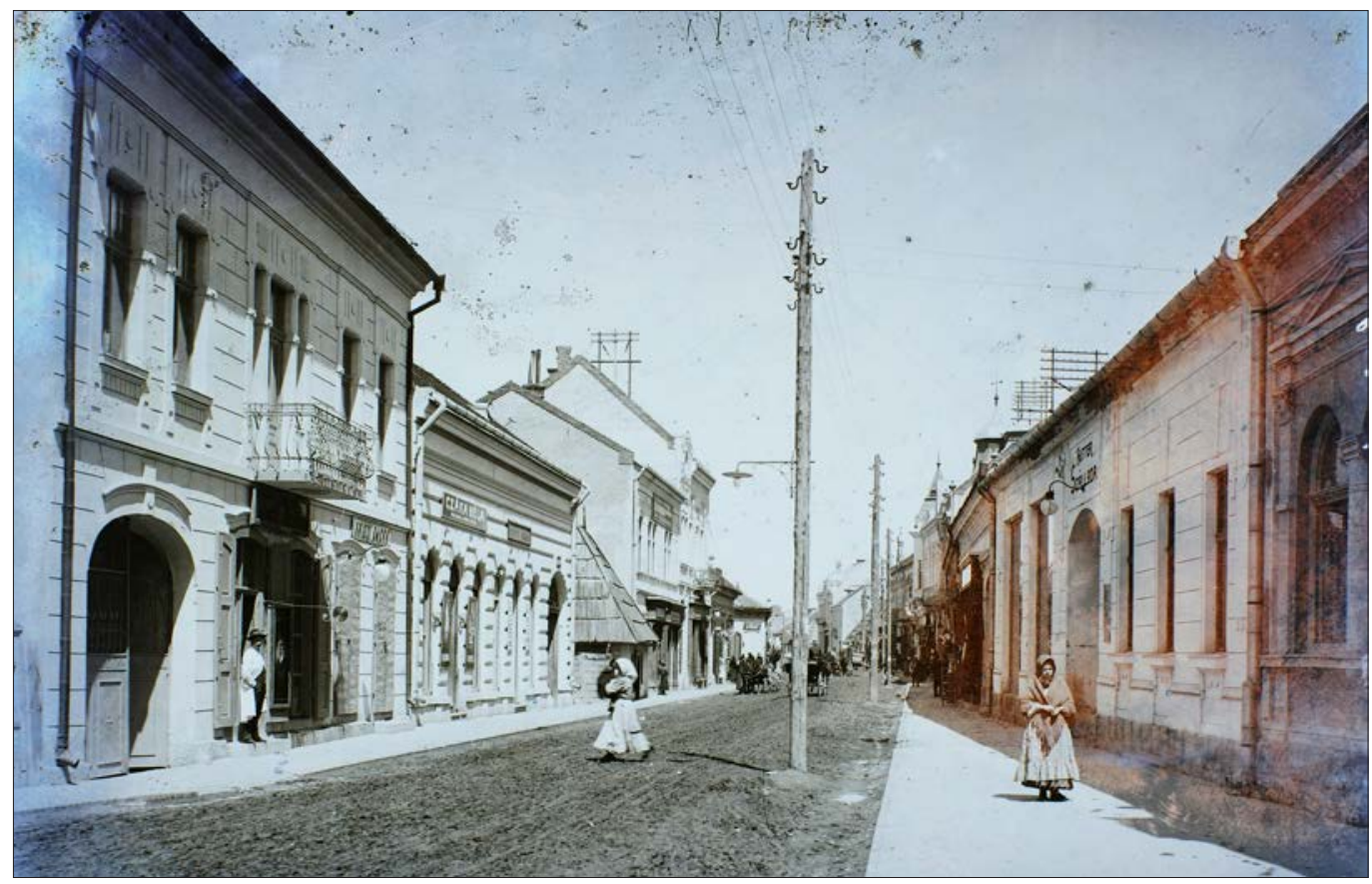

2. kép. Csíkszereda az 1910-es években (fortepan.hu) 
hogy a telefon kábelét Pototzky Pál és Nagy Gyula üzlete közé, az úttest alá behelyezzék és a vezetéket megfelelóleg áttegyék. A munkálatokkal Halász mérnök van megbízva, érthetetlen okból azonban a munkálatok oly lassan és nagy pausákkal haladnak, hogy kilátás van arra, miszerint azok még egy jó hónapig is eltartanak." (Villanyvilágitásunk 1911) Végül is a borúlátó polgárnak nem lett igaza: 1911. február 11-én mégis kigyúlt a villany Csíkszeredában. „Vasárnap már a magánlakásokban is a villany szórta a fényt, mely itt ép oly kifogástalan jó, mint az utcákon. Értesülésünk szerint eddig 2400 láng városunkban, de ez a szám rohamosan fog emelkedni, most igen sokan azt tartották, hogy előbb »lássuk a medvét«. Most mindenki megygyőződött a villany előnyeiről és jóságáról, épen ezért kevesen lesznek, kik annak bevezetése elól elzárkóznak. A villamosmü a Ganz cég szolidságát és megbízhatóságát dicséri." (Villanyvilágitás 1911)
A budapesti Ganz-féle villamossági Rt. 1910-ben építette fel Csíkszeredában áramfejlesztő telepét, és átadáskor két darab 40 lóerős dízelmotorral rendelkezett, generátorokkal együtt. A telep 3100 volt, 42 periódusú háromfázisú váltakozó áramot termelt.

$\mathrm{Az}$ első csíkszeredai villanytelep egyik áramfejlesztője az 1990-es években még Csíkszentkirályon, a malomban megtalálható volt, de nem múködött. Ma már nincs meg leadták ócskavasba.

A csíkszeredai elektromos múvek első igazgatója a körmendi születésű Hodossy Kálmán (1882-?) volt, aki Pápán, majd Budapesten szerzett oklevelet, és Németországban, Gödöllőn és Gyöngyösön végzett szakmai gyakorlatot (Dávid József 1941). Hodossy Kálmán - megszakításokkal - évtizedekig vezette a vállalatot.

1913 elején megállapodás született az államvasutak igazgatósága és a város között a vasútállomás villanyvilágításáról. „A villany

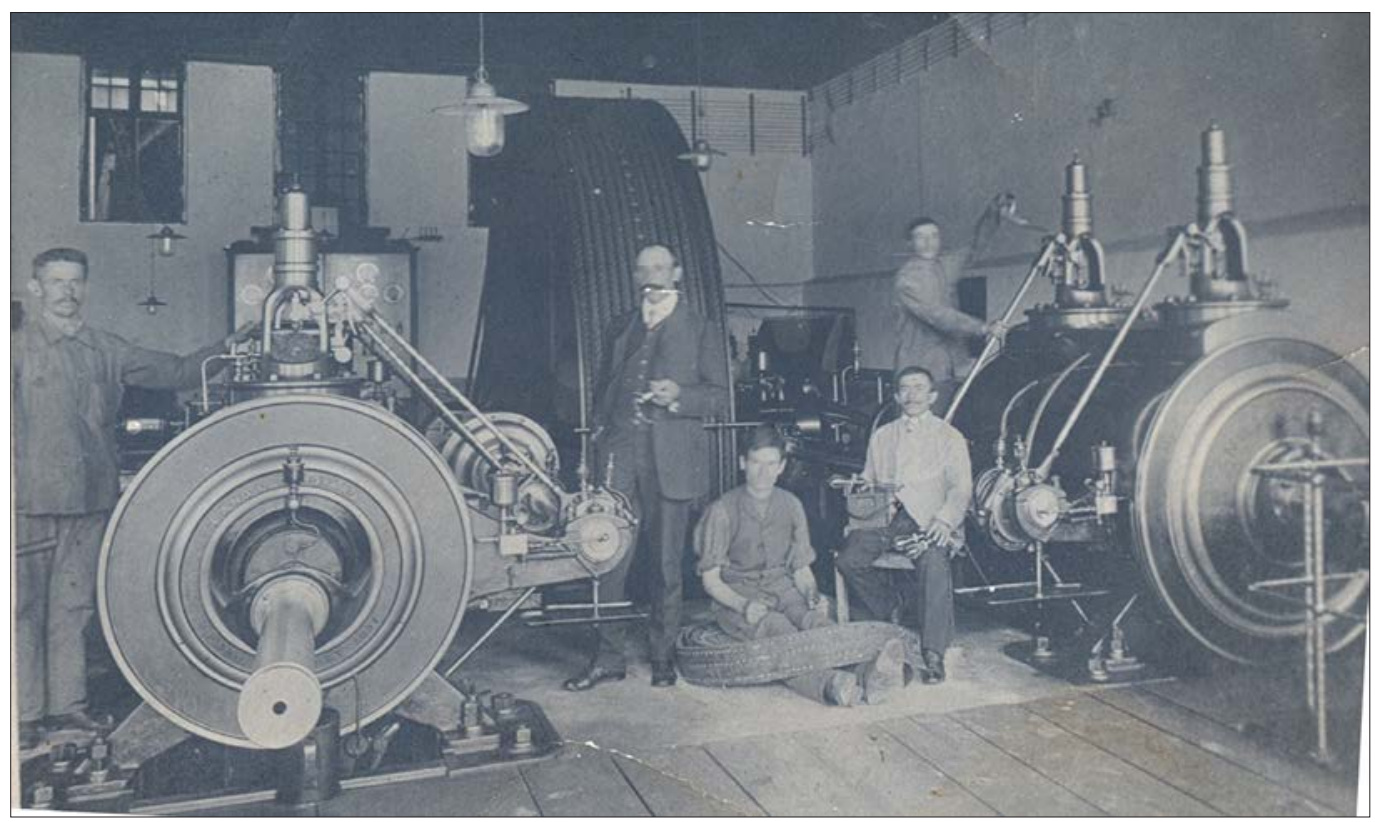

3. kép. A csíkszeredai villanyüzem (a fotó a Csíki Székely Múzeum tulajdona) 


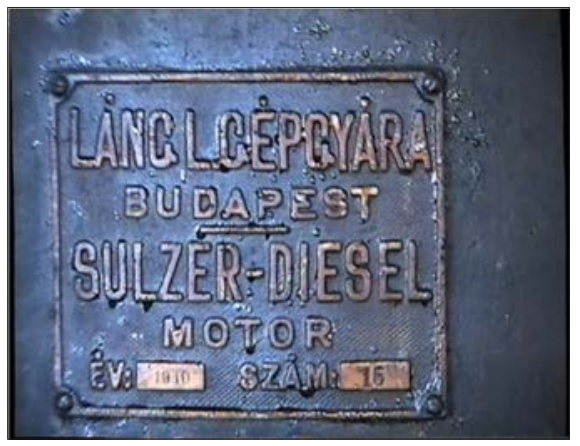

4. kép. A csíkszeredai villanytelep egyik első áramfejlesztőjének felirata (Daczó Katalin felvétele)

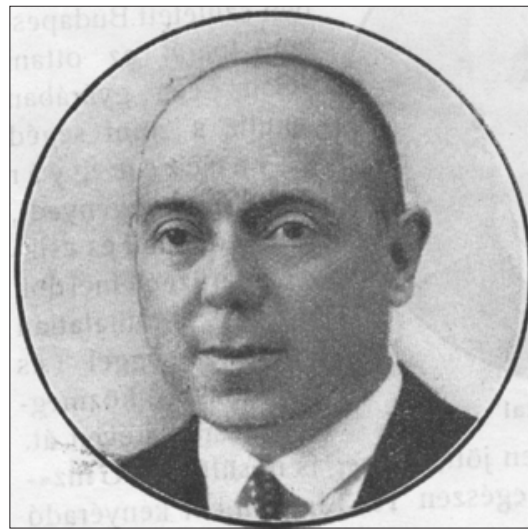

5. kép. Hodossy Kálmán, az első igazgató (Az 50 éves Ipartestület 1934)

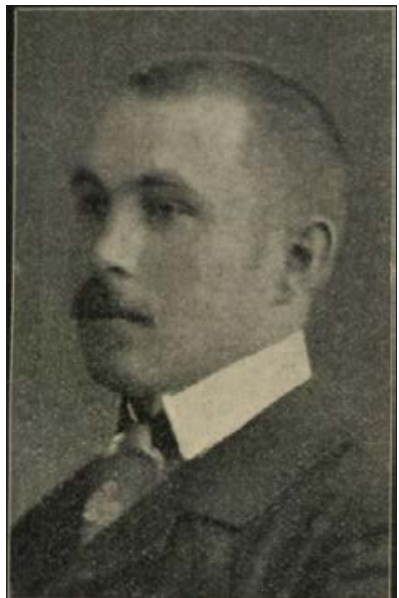

6. kép. Ujfalusi Jenő polgármester - akit dicsértek és kritizáltak a villany miatt az összes helyiségekbe bevezettetik, a pályaudvart pedig 8 darab ezer gyertyafényü Wolfram lámpa fogja megvilágitani" - adta hírül a Csíki Lapok. (A vasuti állomás villanyvilágitása 1913)

„Villanyvilágitás van-e, avagy faggyugyertyát égetünk?”- tette fel a kérdést ismét „egy polgár" 1913 júliusában (Villanyvilágításunk mizériái 1913). „Vagy van villany, vagy nincs?” - kérdezte „egy polgártárs” azok közül, akik röpke két év alatt hozzászoktak az elektromos áram áldásaihoz, de az áramszolgáltatás akad ozott, mert a két áramfejlesztő nem bírta a megterhelést, annak ellenére, hogy csak éjszaka volt áram. Éppen ezért 1913 szeptemberétől egy harmadik gépet is üzembe helyeztek, így már három darab dizelmotor szolgáltatta a villanyáramot 200 lóerő, illetve 136 kilovoltamper összteljesítménnyel (Vécsey Gyula 1938). Ettől a beruházástól remélték, hogy lehetővé válik a nappali áramszolgáltatása is 1914. augusztus 1-től (Villanyvilágítás Zsögödön 1914). „Sajnos azonban e feltétlenül jó hírrel szemben fel kell hívnunk Ujfalusi Jenő polgármester ur figyelmét azon általános és mindennapos panaszra, hogy az áram ereje annyira meggyöngült, miszerint kétszer oly erôs világítás sem éri el a fénynek eredeti erejét. Ezen segíteni kell, még pedig gyorsan és gyökeresen, mert ellenkezö esetben a villanymizeriákra irányuló panaszoknak állandó rovatot kell nyitnunk." (Nappali villamos áram 1913)

\section{Háborús idők}

Az első világháború idején gyakran esett szó a lapok hasábjain az elektromos áramszolgáltatás akadozásáról és drágulásáról. Az akkori állapotokról az egyik cikkből érzékletes képet kaphatunk. „Nagypénteken este megint megfenyegetett a sötétség. A lakásokban felgyúlt a villany este félhétkor és el- 
aludt 10 kor, az utcán egy percig sem gyúlt fel s elterjedt a vészhir, hogy ezután sötétben maradunk, mert elfogyott a benzin. - Nem azért említjük ezt, mintha olyan nagy veszedelmet látnánk abban, ha egy emberi alkotás egyegy pillanatig felmondja a szolgálatot, se nem azért, mintha a mi eredeti nagy sötétségünket kizárólag villannyal vélnók eloszlatni, hanem egyszerüen annak konstatálására, hogy a mi villanyunk nem egy mucsai nyegócás üzlet, hol a szappan, gyertya és bors árát azonnal felemeli, vagy az árulást rögtön beszünteti a mucsai boltos, ha a lova megsántul s az uj szállítmányt nem tudja e miatt a vasútról elhozni. Nálunk egy nagy világcég firmája alatt szolgáltatják a villanyt s el akarják velünk hitetni, hogy ennek a nagy cégnek a háború miatt épen csak Csíkszeredában fogy el a benzine $s$ ezen cimen nagy parlamentirozások után felemelik a villany árát 40\%-kal, söt hogy ezt a fogást indokolják, néha sötétséget is rendeznek. Hát a mi boldog tudatlanságunk és hozza nem értésünk lehet világhírü, de azt az egyet még sem lehet nálunk mindenkivel elhitetni, hogy egy nagy világcég üzleti konjunkturái épen a csíkszeredai vállalat esélyei miatt forognának kockán, mert a Ganz cégnek minden órában módjában áll a csíkszeredai villanyvilágításhoz szükséges benzint a legkisebb lájbi zsebéből hozzánk liferálni. A 40\%-os árfelemelés indokául pedig ne akarják elhitetni velünk, hogy a nagy világcég a világításhoz szükséges benzint Szereda számára naponkint, vagy épen litrenként és a háború esélyei szerint szerezgeti be s annak konkurrens ára szerint kell a villany árát hol felemelni, hol leszállítani. Ez a feltevés szégyent vetne a nagy cégre, mely nem a mucsai boltos, s a mellett nagyban dehonesztálja azt a percentes hasznot, melyet a városi közjövedelmek között olyan nagy féltékenységgel szoktak védelmezni." (Megint a villany 1915)

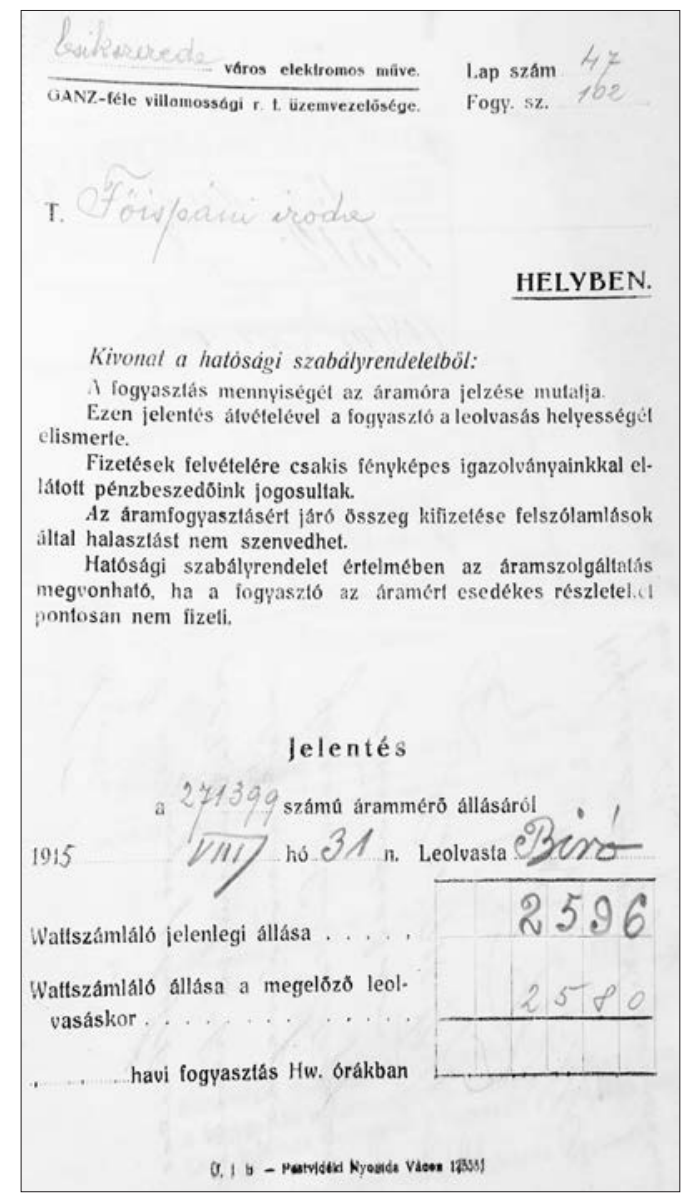

7. kép. Jelentés a föispáni iroda árammérőjének állásáról

A háború vége felé, 1918-ban minden fogyasztót villanyóra vásárlására köteleztek, ugyanis 49 órás fogyasztón kívül a korábban létező 338 átalányfogyasztó igen nagy égőket kezdett használni, és rendkívül megnövekedett a terhelés. Ezért „át kellett térni az órával való fogyasztás-mérésre és kényszeríteni kellett a fogyasztó közönséget óra vételre és ezáltal automatikusan a fogyasztás csökkenés állott elö, mindenki igyekezett takarékoskodni, mert az óra minden kis fogyasztást mutatott" (Vécsey Gyula 1938). 


\section{$A$ villanytelep és a város}

A Ganz céggel 1910-ben kötött egyezség értelmében „a villanytelep évi tiszta nyereségén fele-fele arányban osztozott az rt. és a város", azzal a kikötéssel, hogy ha "az üzemév veszteséggel záródna, azt egészében a város köteles fedezni". Az első éveket a villanytelep mérsékelt nyereséggel zárta, a háború éveiben viszont veszteségessé vált, és ez a város anyagi helyzetét is súlyosbította (Vofkori György 2007).

A háborút követően, 1920 novemberében Tetiu Aurel polgármester felmondta a szerződést, arra gondolva, hogy a város házi kezelésbe veszi a villanytelepet, és majd olcsóbban állítja elő a villanyáramot. Válaszul a Ganz cég táviratban értesítette a csíkiakat, hogy a felmondást - az aláírt szerződés értelmében - csak az 1921. december 31-i időponttól fogadja el. Hajlandó lett volna viszont a szerződés felbontásáról tárgyalni, ha a „300 000 koronát kivető tartozását a város rendezi" (Vofkori György 2007). Végül 1921. december 25-én arról adott hírt az újság, hogy „egy évig még a Ganz marad” (A villanyvilágitás ügye 1921), de az egy évből több is lett, bár elképzelhető, hogy egy kis kihagyással. „Bölcs városatyáink a villanytelepet 1929. január elsejétöl számított 15 esztendőre Ganzéknak újból bérbe adták" (Legyen olcsóbb a világitás 1931) - jegyezte fel nem kis rosszallással Frank Miklós mérnök, és valóban, az 1940-es években még mindig a Ganz múködtette a csíkszeredai villanytelepet.

Néhány működési adat: az 1934-ben megjelent ipartestületi emlékkönyv szerint ebben az időben az áramot oszlopokra szerelt szabadvezetékek juttatták el a város különböző részein működő $17 \mathrm{db}$ transzformátorig, ahol a 3100 voltos primer áram 3-szor 110 voltos szekunder használati feszültségre alakult át. 1934-ben a primer vonal 6 km,

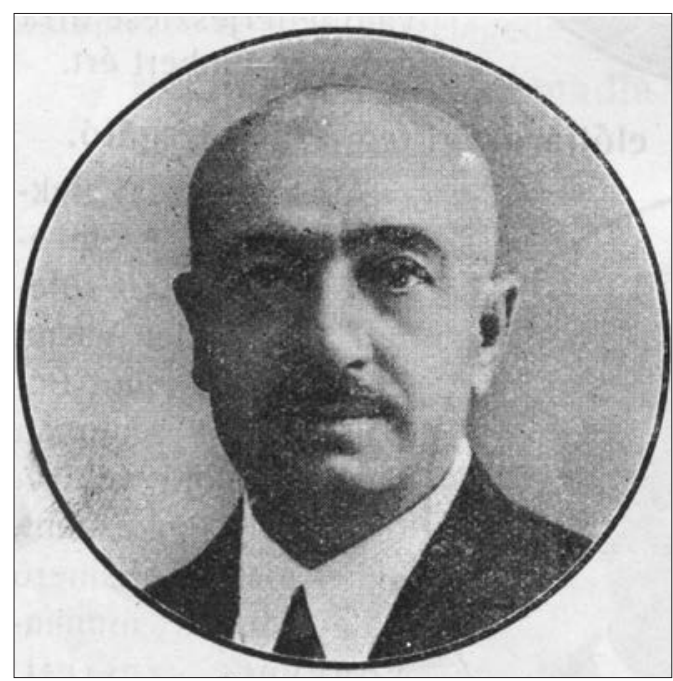

8. kép. Paulovits Antal villanyszereló, vállalkozó

míg a szekunder huzalok majdnem 15 kilométer hosszan voltak beépítve. A Ganz cég vállalta világítási, erőátviteli berendezések tervezését, szerelését községek, gazdaságok és lakások részére. Saját gépjavítóműhelyt működtetett, és mérőberendezés állt rendelkezésére az árammérők, műszerek és áramfogyasztó tárgyak pontos ellenőrzése céljából (Csíkszereda város villamosmúve 1934).

Itt kell megemlítenünk a korszak egyik legismertebb szakemberét, Paulovits Antal budapesti születésű villanyszerelőt, aki 1912-ben jött Csíkszeredába a Ganz cég alkalmazottjaként, és akinek 1933-ban kenyéradó gazdái a gazdasági válságra hivatkozva felmondtak. Paulovits Antal 1884-ben született Budapesten, és a mesterséget ugyanott, a Ganz cégnél tanulta. Leépítése után Paulovits Antal villanyszerelési vállalatot alakított (Paulovits Antal villanyszerelő 1934).

\section{Kinek kellett a fény?}

A 20. század elején még igencsak megoszlottak a vélemények az egyes községek villamosításának kérdésében. A helyi tanácsosi 
testületek nehezen ismerték fel a villamos energia bevezetésének jelentőségét, a kezdeményezők ezért igyekeztek minél nyomósabb érvekkel előállni. A Csíkszentmárton és Csekefalva községek villamos közvilágításának létesítését felvállaló Alcsíki Bank Rt. képviselője így foglalta össze a villany bevezetésétől várható változásokat 1918-ban: „villany ég a szobában, istálóban, nem kell bajlódni a lámpa, lámpaüveg, bél és petróleum beszerzésének mind nagyobbá váló nehézségeivel, nincs lámpatakarítás, nincs korom, füst és rossz levegő a szobában, - nincs tüzkár, melyet nagyon sok esetben a petróleumlámpa és gyertya, ezek meggyújtásakor eldobott gyufa okoz. A kivilágított utcákon nagyobb a közbiztonság, és mert a villanyvilágítás óriási lépést jelent a fejlődés, a haladás útján, fejlettebb községekben pedig értékesebb minden, többet fog érni itt a közvagyon, magánvagyon egyaránt." (Alispáni iratok 1918)

A meggyőzés Csíkszereda közvetlen szomszédjainál sem ment könnyebben. A hálózat jövedelmezősége érdekében a Ganz gyár tisztviselői több ízben is tárgyaltak a ma Csíkszeredához tartozó, de akkor még önálló Csíktaploca, Csíkzsögöd és Csíksomlyó községek elöljáróságaival a villanyáram bevezetése ügyében (Villanyvilágítás Csíktaplocán 1914), de hosszú évekig elutasításba ütköztek. A csíktaplocai tanácsülés 1911ben egyhangúan úgy döntött, hogy: „a község anyagi helyzete a villanyvilágítás bevezetését nem engedi meg. - A jól értesültek még azt is tudják, hogy e határozat létrejöttét nagyban elösegítette az egyik képviselö-testületi tag következő érvelése: „Eddég es láttunk alunni villany nélkül: ezután es látunk!..."“" (Gál Sándor 1935).

1914-ben ismét felvetődött a villany bevezetésének ügye Zsögödön és Taplocán, s ezt valószínűleg az időközben kirobban vi- lágháború akadályozta meg. Így, a háborút követően, még 1921-ben is napirenden volt a Csíkszeredával egybeépült települések villanyhálózatának kiépítése, sőt 1931 novemberében még mindig csak arról olvashatunk, hogy Zsögöd területén a Ganz cég megkezdte a villanyhálózat kiépítését ( $A$ csíksomlyói községi tanács és a villanyáram 1933), majd 1932-ben bekapcsolódott a hálózatba (Szendy Károly 1941). 1933-ban a csíksomlyói tanács is határozatot fogadott el a villanyáram bevezetéséről. De nem ám egyszerúen - történt ugyanis, hogy negyven csíksomlyói polgár „,beadványt intézett Csikszereda városhoz, a villanyvezetéknek Somlyóra való meghoszszabbítása tárgyában. [...] Hogy hogy nem a villanyáramnak mint kulturjelenségnek Csiksomlyóra való kivezetésérôl tudomást szerzett a községi tanács is. Gyorsan összeült. Határozni afelöl, hogy milyen álláspontot foglaljanak el ebben a roppant érdekes kérdésben. Engedjék vagy ne az áramot Somlyóra. És mit tetszik gondolni, egyhangúan, megható nagylelküséggel úgy határoztak, hogy megengedik. A község. Mert szerintük nekik semmi közük annak a negyven somlyói lakónak a privát kezdeményezéséhez, akik villany luxust akarnak üzni. [...] Azonban árat szabtak ennek az áldozatos határozatuknak. Közölték Csíkszereda városával, hogy a villanyt csak úgy engedik be, ha a város ingyen ellátja Somlyó községnek 8 lámpával való közvilágítását és a községházának gondoskodik az állandó díszvilágításáról. Természetesen Csíkszereda közölte a községi tanáccsal, hogy a közvilágitást a városnak is meg kell fizesse. A város szívesen támogatja a község lakosságának az áramnyújtásra vonatkozó kérését, azonban ezért ráfizető áldozatot a község nem kívánhat." (A csíksomlyói községi tanács és a villanyáram 1933)

Végül 1934-ben Csíksomlyón is kigyúlt a villanyfény (Szendy Károly 1941), és ün- 
„Bevezetik a villanyt a híres csiki búcsújáróhelyre. Mercurea-Ciuc (Csikszereda). Saját tud. A városhoz közelfekvő összeépült Ciucsumuleu (Csiksomlyó) községbe, az országosan híres Mária búcsújáróhelyre, a városi Ganz villanyüzem megkezdte a villanyvilágitás bevezetését, úgyhogy az a közel jövőben már meg is valósul. A hires búcsújáróhely és az ősrégi zárda, valamint az évszázados kegytemplom sokat nyer már idegenforgalmi szempontokból is a villanyvilágítással. Itt emlitjük meg, hogy Hodossy Kálmán villanyüzemi igazgató tervei szerint a zsögödi közvilágitási lámpák szaporitását és intenzivebb áramszolgáltatást is kilátásba helyeztek." (Csíki Lapok 1934. julius 22.)

nepélyesen megvilágították a csíksomlyói Szűzanya kegyszobrát is (A somlyói kegytemplomban 1934). 1938-ban a hargitafürdői villanyvilágítás bevezetésére tartottak árlejtést (Hargitafürdő villanyvilágítása 1938), tehát folyamatosan emelkedett a hálózatra csatlakozott személyek száma. „Jelenleg a helyzet 842 órás fogyasztó és 13 átalányos szerepel a kimutatásban és már $358 \mathrm{~kW}$ a beépített felvevő képesség. Mi lenne ha mindenki bekapcsolná összes lámpáit és motorait?A teljesítőképesség 106 kW és a fogyasztóképesség 358 kW. Szerencsére az egyidejü terhelés még 105 kW körül mozog" - foglalta össze Vécsey Gyula 1938 augusztusában, sürgetve új gépek vásárlását a villanytelep részére (Vécsey Gyula 1938).

1939 márciusában már azt adta hírül az egyik helyi lap, hogy új gépeket kap a villanytelep, mert „a városi villanytelep erőforrásához kapcsolt zsögödi és somlyói házak megvilágításával túlterhelt gépek már nem bírják a kellő mennyiségü áramot szolgáltatni" (Csikszereda város 1939).

\section{Új világ fényei}

1940 őszén, a második bécsi döntés után a lapokban megjelentek a Tungsram reklámok, hamarosan pedig megkezdődött a falvak villamosítása. „Dr. Varga József Ipar- és keresk. miniszter a tudós felkészültségével beszélt a megvalósítás előtt álló székelyföldi kérdésekröl. A Székelyföld villamosítása rövid idő kérdése. Egy hónapon belül megalakul a részvénytársaság s 200 székely községet látunk el elektromos árammal. Ebben az évben már 15 községben égni fog a villany. Nem vizi erötelepeket használunk. Gázkincs hasznosításán fog alapulni a Székelyföld villanyellátása." (A magyar kormány csikmegyei látogatása 1942)

1942 októberében Csíkszereda tanácsa a villanyhálózat Zsögödfürdőig való meghosszabbításáról döntött (Csíkszereda költségvetési előirányzata 1943.). „Csíkmegye villamosítása Csíkszeredából kiindulva rohamlépésben érhet célba"- írta a Csíki Lapokban Ferencz Gyárfás 1943. január 17-én. Ekkor már hét alcsíki községben is égett a villany (Gyárfás Ferenc 1943).

1943. december 31-én, több mint 32 év után, lejárt a Városi Villamosmű üzembérletére vonatkozó szerződés a Ganz és Társa Rt.-vel, s mivel a Székelyföldi Villamosművek Rt.-vel folytatott megbeszélések 1944 februárjáig nem vezettek eredményre, Csíkszereda házi kezelésbe vette a villanyüzemet. A Csíki Lapok beszámolójából kiderül, hogy valóban megtörtént a házi kezelésbe vétel, s hogy egy „kivénhedt villamosműről” van szó, így fokozottan figyelni kell a takarékosságra, különben sötétben maradhat a város. A városnak viszont „minden körülmények között kötelessége, hogy a mozi vasárnap délután 3 órakor áramot kapjon" (Városi közgyülés 1944). 
Az 1944. augusztus végi kiürítéskor a németek állítólag felrobbantották az üzemet. A robbantást átvészelő egyetlen gép ezután csak a kórházba, az orosz parancsnoksághoz és a megyeházába tudta eljuttatni az áramot. 1944-45 után, a menekülésből hazatérve Fénya Károly és Vécsey Gyula vezetésével a megmaradt felszerelésekből, alkatrészekből újabb villanytelep jött létre a mai villamossági vállalat székhelyén, és ezzel új fejezet kezdődött a csíkszeredai villanyüzem életében, amely 1963 októberéig tartott. Közben, 1962-ben, Csíkszeredát bekapcsolták az országos hálózatba, de este, „csúcsfogyasztás idején a város villanytelepe egy rövid esztendeig beszolgált az országos hálózatba" (Vofkori György 2007).

\section{Felhasznált irodalom}

Dávid József (szerk.): Székelyföld írásban és képben. Budapest, 1941.

Gál József: Csíkszereda múltja és keletkezése. Kézirat, 1970.

Gál Sándor. Érdekességek Csiktaplocza község múltjából. Csíki Lapok 47. évf. 50. sz. (1935. december 15.) 2.

Gyárfás Ferenc: Csíklázárfalván minden házban villany ég. Csíki Lapok 55. évf. 3. sz. (1943. január 17.) 2.

Herczka Gyula: Villamos világitas... Csíki Lapok, 9. évf. 50. sz. (1897. december 15.)

Herczka Gyula: (reklám) Csíki Lapok, 21. évf. 16. sz. (1909. április 14.) 4.

Hodossy Kálmán In: Az 50 éves Ipartestület 1884-1934. Csíkszereda és Vidéke Ipartestülete, Csíkszereda, 1934. 65.

Szendy Károly (szerk.): Magyar városok. Vármegyei Szociográfiák Kiadóhivatal, Budapest, 1941.

Tirvai Nagy Imre: Emlékezés régi csíkiakról. 2. kiadás. Pallas-akadámia, 1996.

Vécsey Gyula: $A$ villanytelep ügye vagy karácsonykor vajjon petroleum-lámpával világitunk-e? Csíki Lapok, 50. évf. 30. sz.
(1938. aug. 21.) 3.

Vofkori György: Csíkszereda és Csíksomlyó képes története. Typografika, Békécsaba, 2007. 270-274.

A csíksomlyói községi tanács és a villanyáram. Csíki Lapok, 45. évf. 44. sz. (1933. okt. 29.) 2.

A föispáni iroda villamos világítási lámpáinak beszerzése. Direcția Județeană Harghita a Arhivelor Naționale (Román Nemzeti Levéltár Hargita Megyei Igazgatósága), Fond 7 Prefectura Județului Ciuc (Csík megyei prefektúra iratai) - Subprefect (inv. 4) Alispáni iratok (4. számú leltár) 978/1915

A magyar kormány csikmegyei látogatása. Csíki lapok - 54. évf. 25. sz. (1942. június 21.) 2.

A somlyói kegytemplomban. Csíki Lapok - 46. évf. 29. sz. (1934. julius 15.) 4.

A vasuti állomás villanyvilágitása. Csíki Lapok,. 25. évf. 16. sz. (1913. ápr. 16.) 3.

A villanyvilágitás ügye. Csíki Lapok, 33. évf. 52. sz. (1921. dec. 25.) 1.

Aerogén-gázvilágitás. Csíki Lapok, 16. évf. 42. sz. (1904. okt. 5.) 3.

Alispáni iratok. Direcția Județeană Harghita a Arhivelor Naționale (Román Nemzeti Levéltár Hargita Megyei Igazgatósága), Fond 7 Prefectura Județului Ciuc (Csík megyei prefektúra iratai) - Subprefect (inv. 4) (4. számú leltár) 13125/1918.

Csíkszereda költségvetési előirányzata. Magyar Országos Levéltár (K150. 3526. IV. 30. tétel) Városok ügyei - Csíkszereda. 239/1943.

Csikszereda város. Csíki Néplap, 9. évf. 9. sz. (1939. márc. 8.) 1-2.

Csíkszereda város villamosmüve. In: $A z 50$ éves Ipartestület 1884-1934. Csíkszereda és Vidéke Ipartestülete, Csíkszereda,1934. 104-105.

Csíkszereda világitása. Csíkszereda, 2. évf. 40. sz. (1904. szept. 25.) 2-3.

Elektrotechnikai és müszaki üzlet. Csíki Lapok, 12. évf. 29. sz. (1900. julius 18.) 
Haladunk. Csíki Lapok, 16. évf. 41. sz. (1904. szept. 28.) 2.

Hargitafürdő villanyvilágítása. Csíki Lapok, 50. évf. 24. sz. (1938. jún. 12.) 2.

Legyen olcsóbb a világitás. Csíki Lapok, 43. évf. 7. sz. (1931. febr. 15.) 2.

Megint a villany. Csíki Lapok, 27. évf. 14. sz. (1915. április 7.) 3.

Nappali villamos áram. Csíki Lapok, 25. évf. 48. sz. (1913. nov. 26.) 3.

Paulovits Antal villanyszerelő. In: Az 50 éves Ipartestület 1884-1934. Csíkszereda és Vidéke Ipartestülete, Csíkszereda, 1934. 66-67.

Új világitás. Csíki Lapok, 20. évf. 9. sz. (1908. február 26.) 2

Villamos világitás. Csíki Lapok, 13. évf. 41. sz. (1901. október 9.) 3.

Villamos világitás Csik-Szeredában. Csíki Lapok, 9. évf. 16. sz. (1897. április 21.) 1.

Villámvilágitás és egyiptomi sötétség. Csíki Lapok, 16. évf. 40. sz. (1904. szept. 21.) 3
Városi közgyülés. Csíki Lapok, 56. évf. 9. sz. (1944. február 27.) 1-2.

Városok ügyei - Csíkszereda. Csíkszereda költségvetési elöirányzata. Magyar Országos Levéltár (K150. 3526. IV. 30. tétel) 239/1943.

Villanyvilágítás. Csíki Lapok, 23. évf. 7. sz. (1911. február 15.) 2.

Villanyvilágitás. Csíki Lapok, 43. évf. 44.sz. (1931. november 1.) 4.

Villanyvilágítás Csíktaplocán. Csíki Lapok. 26. évf. 25. sz. (1914. június 17.).

Villanyvilágitás városunkban. Csíki Lapok, 21. évf. 16. sz. (1909. ápr. 14.) 2.

Villanyvilágítás Zsögödön. Tárgyalások. Csíki Lapok, 26. évf. 27. sz. (1914. július 1.) 3.

Villanyvilágitásunk. Csíki Lapok, 23. évf. 4. sz. (1911. január 25.) 2.

Villanyvilágításunk mizériái. Csíki Lapok, 25. évf. 31. sz. (1913. júl. 30.) 4. 


\section{A VILLAMOSÍTÁS ELSő ÉVTIZEDEI SZÉKELYUDVARHELYEN}

A 20. század kezdeti éveiben Székelyudvarhelyen a közvilágítást még mindig a petróleumlámpák kizárólagos egyeduralma jellemzi, ami nem volt kuriózum azokban az években a Székelyföldön. Faoszlopokra, épületek falára rögzített öntöttvas lámpatartó konzolokra szerelt, üvegablakokkal ellátott vaslemez dobozokban elhelyezett petróleumlámpák voltak a közvilágítás egyedüli eszközei. A lámpákat egy lámpagyújtó személy kezelte, ami abból állt, hogy szürkületkor, létra használatával felment a lámpához, kinyitotta a doboz ablakát, begyújtotta a lámpa kanócát (lámpabelet), ami a petróleumba merülve felszívta a világítva égő petróleumot. Ekkor már használatban volt a gyufa, amelynek meggyújtásához elegendő volt a ruházathoz súrolni, amitől lángra lobbant. Ezzel a gyufaszállal gyújtotta meg a kanócot a lámpagyújtó, majd becsukta a lámpatartó ablakát, leereszkedett a létrán, majd a következő lámpánál megismételte ugyanezeket a múveleteket.

Székelyudvarhelyen még 1904-ben is ezt a közvilágítást alkalmazták, és ehhez 165 darab utcai lámpát használtak (Udvarhelyi Híradó 1906. március 25.). Reggelig világítottak a lámpák, amikor a lámpagyújtó ismét végigjárta az oszlopokat, eloltotta a lámpákat feltöltötte tartályukat petróleummal, megtisztította a kormos üvegeket, majd visszacsukta a lámpatartó ajtaját. A lámpa készen állt az esti begyújtásra.

Az Udvarhelyi Híradó 1904. szeptember 11-i számában jelent meg az a hír, amely- ben a budapesti Ganz és Társa Rt. bemutatta ajánlatát a Polgármesteri Hivatalnak, és tárgyalásokat kezdeményezett villamos energia előállításával és felhasználásával kapcsolatosan Székelyudvarhelyen (Udvarhelyi Híradó 1904. szeptember 11.).

$\mathrm{Az}$ első ajánlat szerint az áramfejlesztő generátorokat vízenergiával, a régi malom helyén felállított törpe vízerőmúvel üzemeltették volna. A meghajtó erőforrás egy Francis típusú vízturbina lett volna. A $240 \mathrm{~V}$ hálózati feszültség egyenáramú rendszerben müködött volna, arra hivatkoztak, hogy a vízturbina kapacitása, az általa meghajtott generátor nem termeli azt a villamos energiát, ami abban az időben megfelelt volna a város szükségleteinek (Udvarhelyi Híradó 1904. szeptember 11.). A különbözetet akkumulátortelepek párhuzamos működtetésével tervezték megvalósítani. Éjjel, amikor a fogyasztás csökken, töltötték volna az akkumulátorokat, majd a csúcsfogyasztás alatt kapcsolták volna ezeket a generátorokkal párhuzamosan a termelt elektromos energia kiegészítése céljából.

Számos elemzés és bírálat követte a Ganz és Társa ajánlatát, aminek az lett az eredménye, hogy a vízturbina kapacitását egy 60 LE-s gőzgéppel kiegészítve újabb energiatermelést reméltek, hiszen az újabb számítások szerint 150 LE primer energiaforrásra lett volna szüksége a városnak (Udvarhelyi Híradó 1904. szeptember 18.).

Ezt látva 1905. április 17-én a város tör- 
vényhatósága megsemmisítette a Ganz és Társa Rt. által előterjesztett és a város elöljárói által aláírt szerződést (Udvarhelyi Híradó 1905. március 19.). Újabb egy év telt el az új szerződés megkötéséig. 1906. június 12-én új szerződés aláírására került sor a Ganz céggel, megnövekedett energiatermelést előírva. Világítási célra 220 volt, ipari célokra 400 volt feszültségű egyenáramú rendszert terveztek.

1906. december 10-én ismét jóváhagyott a közgyűlés egy újabb szerződést a Ganz és Társa céggel. Ez a szerződés 1906. január 27-én érvénybe lépett. A villanytelepet a Nagy-Küküllő mellett, egy régi malom telkére építették. A három nagyobb helyiség 1908-ban készült el 396,9 $\mathrm{m}^{2}$ beépített felülettel (Udvarhelyi Híradó 1906. június 10.).

A villanytelep felszerelése mindhárom helyiséget elfoglalta. Az első helyiségbe helyez- ték el a széngázt fejlesztő 2 darab generátort, valamint a két kompresszort. A kompresszorok az indításhoz szükséges magasnyomású levegőt állították elő. Ezzel hozták forgásba a motor lendkerekét, a széngázos motor indítását.

A középső helyiségben, a tulajdonképpeni gépteremben a 2 darab szívógázmotor és a velük összekapcsolt egyenáramú generátorok kaptak elhelyezést.

A harmadik helyiség az akkumulátortelepeket foglalta magában. Az akkumulátorok, mint említettük, akkor szolgáltattak áramot a városi villanyhálózatba, amikor a fogyasztás lecsökkent és leállították a generátoregységeket. Így takarékoskodtak a széngázzal. A két generátor 220/400 volt egyenfeszültséget fejlesztett. A két rendszer (két gázmotor, két generátor) egyszerre működött,

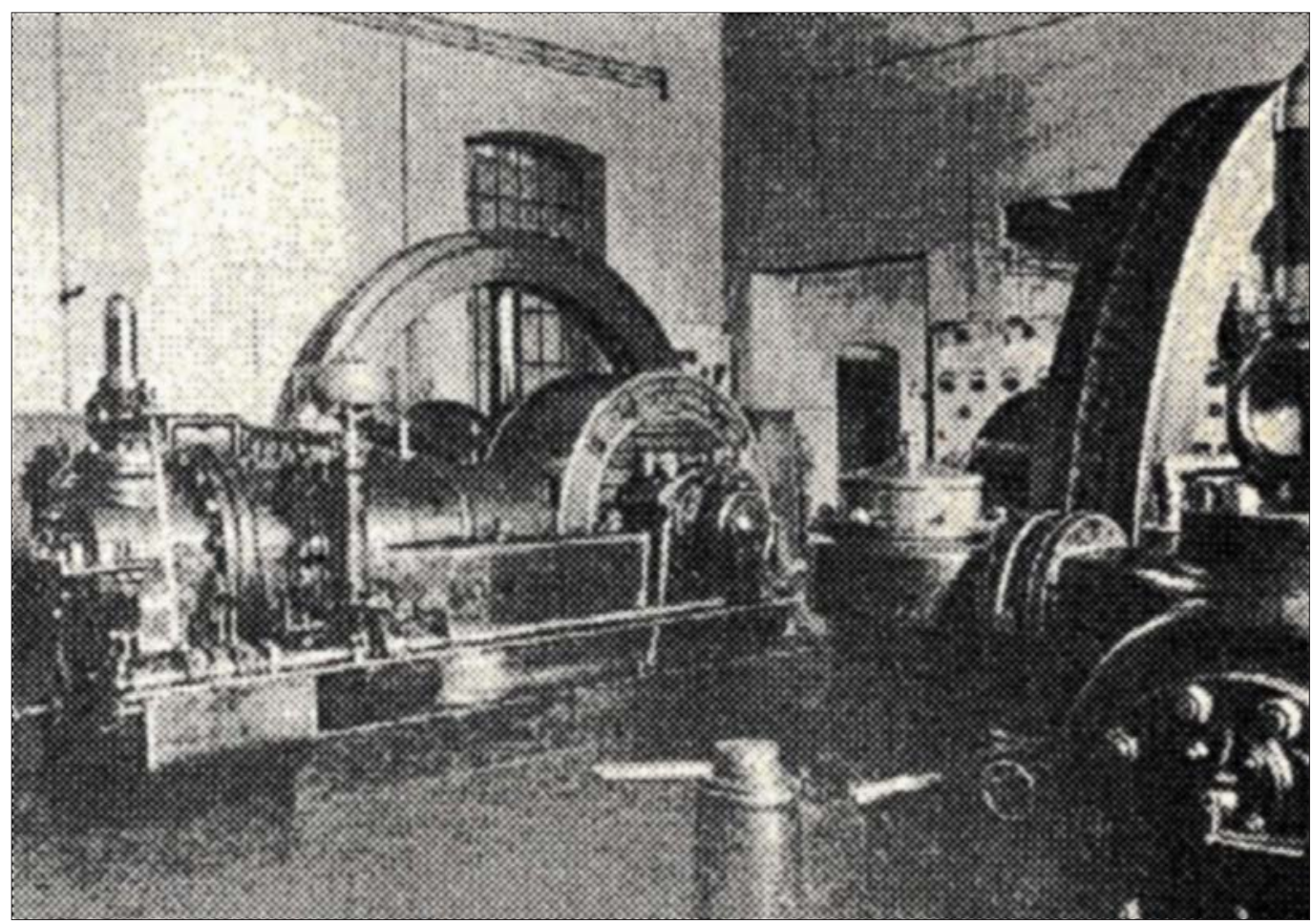

1. kép. A villanytelep gépterme a két szívógázmotorral 
párhuzamosan kapcsolva a városi hálózatra. A generátorokat a Ganz múvek gyártották 1904-, illetve 1907-ben.

A közvilágítást első ízben 1908. május 24-én éjjel helyezték feszültség alá. Ebben a felállításban múködött a villanytelep kisebb-nagyobb üzemzavarokkal, tartalék kapacitás nélkül (Udvarhelyi Híradó 1908. május 31.).

1914-ben kitört az első világháború, amit a villanytelep is megsínylett. Hadi célokra, ólomtartalmának más rendeltetése kapcsán leszerelték az akkumulátortelepet. Így telt el a villanytelep első tízéves működésének időszaka.

A második évtized egyre több üzemzavarral, számos nem várt nehézséggel telt el. A megnövekedett igény kapcsán sürgősen bővíteni kellett a villanytelep kapacitását. Így az első fejlesztést 1930-ban végezték. Ekkor a Ganz cég egy 80 LE-s, kéthengeres dízelmeghajtású generátor üzembe helyezésével növelte a villanytelep kapacitását, remélve, hogy ekkora fejlesztés meghaladja a már megnövekedett fogyasztást. Az összteljesítmény a fejlesztés után 280 LE volt, ami 206 KW villanyenergiát jelentett.

Nagy fogyasztóként lépett be a városi mozi. Vetítőgépe ívfénylámpával múködött, ami a bekapcsolásakor jelentős feszültségesést okozott a hálózaton. Ennek kompenzálására hoztak létre egy villanymotor-generátor csoportot. A motor a hálózati feszültségre kapcsolva meghajtotta a kis teljesítményű generátort, amelynek feszültsége kimondottan a mozigép ívfénylámpáját volt hívatott ellátni feszültséggel. Mindezek mellett egyre sürgetőbbé vált a villanytelep kapacitásának bővítése. Ezt indokolta az is, hogy az évek során

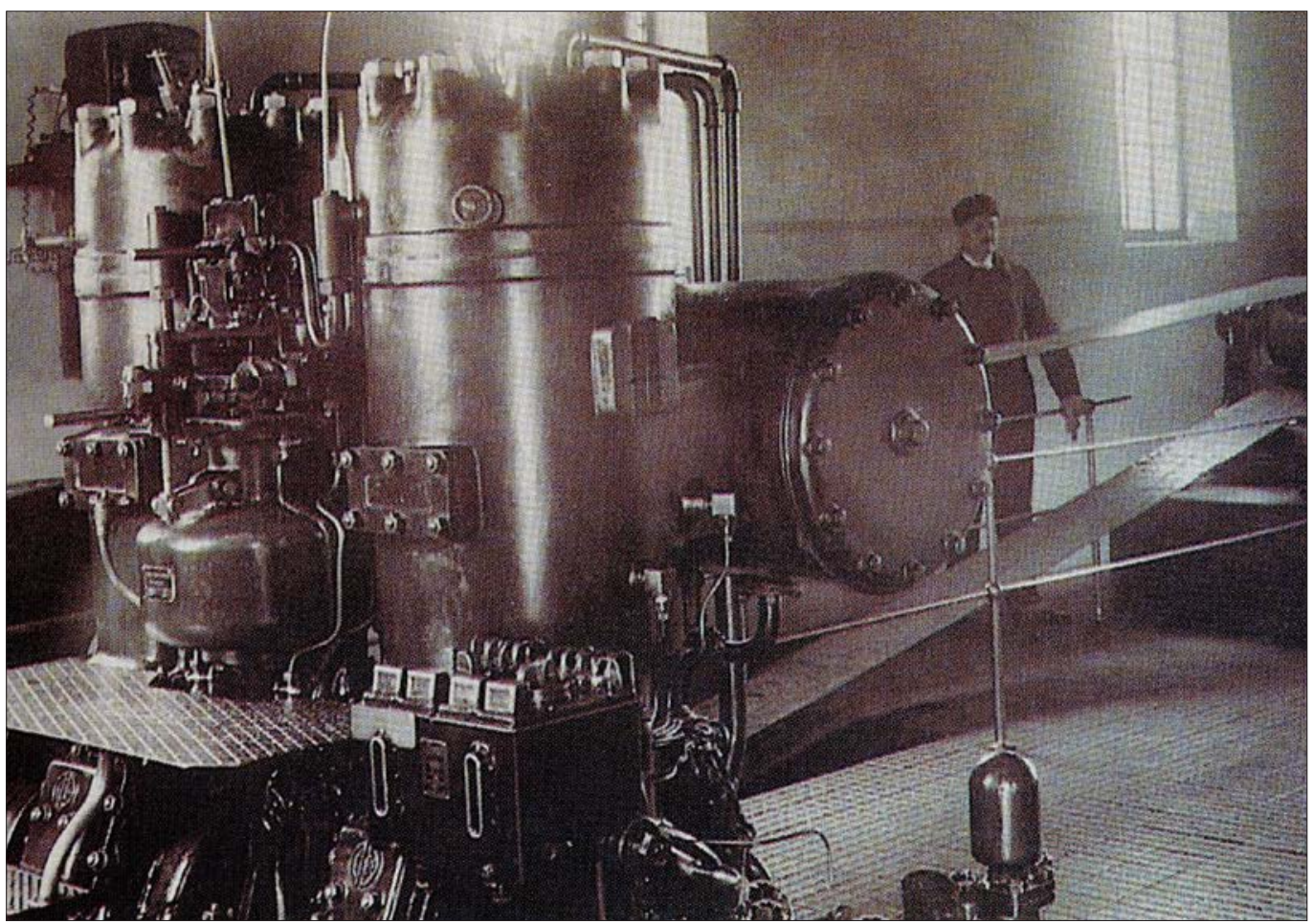

2. kép. Az 1930-as bővités a 80 lóerős, kéthengeres dízelmotorral és dinamójával 
a lakosság lélekszáma az 1930-as 8518 főről 1941-ben 11927 főre emelkedett (Péter Attila 1998, 40.).

1948-ban újabb fejlesztésre került sor, ami jelentős kapacitásnöveléssel jár. Újabb 220,8 KW teljesítménnyel bővült a villanytelep teljesítménye. Ezáltal a telep összkapacitása elérte a 426,88 KW teljesítményt. Megmaradt a két szívógázmotor, a dízelmotoros egység, ezekhez csatlakozott a 220,8KW új dízelmeghajtású egység. A fejlesztés itt sem állt meg. 1952-ben újabb 404,8 KW teljesítménnyel bővült Székelyudvarhely villanytelepének kapacitása. Az új egységet a 80 LE teljesítmény helyébe szerelték. A leszerelt 80 LE kapacitást Miklósfalvára szállították, ott helyezték múködésbe. A kialakult teljesítmény 610, 8 KW. Az utóbbi fejlesztést egy svéd gyártmányú Atlas Polar márkájú, dízelmeghajtású egység jelentette (Péter Attila 1998. 40-42.).

Ez a heterogén szerkezetű villanytelep sem tudta ellátni a város növekvő igényét villamos energiával. A hosszas túlterhelések egyre több üzemzavart okoztak, nem is beszélve az egyenáram alkalmazásának megannyi nehézségéről.

A végleges megoldást az 1959-es év hozta.. Ekkor csatlakozott Székelyudvarhely is az országos váltóáramú ellátórendszerhez. Az ötvenes években megkezdődött az Udvarhely környéki falvak villamosítása is.

Jelen összegzés a néhai Péter Attila székelyudvarhelyi tanár Volt egyszer egy villanytelep című tanulmánykötetének felhasználásával készült, a család utólagos beleegyezésével.

\section{Felhasznált irodalom}

Péter Attila: Volt egyszer egy Villanytelep. Infopress nyomda kiadása, Székelyudvarhely, 1998. 40-42.

Vofkori György: Székelyudvarhely. Várostörténet képekben. Polis Könyvkiadó, Kolozsvár, 1998. 85-88. Udvarhelyi Híradó, 1904. szeptember 1.

Udvarhelyi Híradó, 1904. szeptember 18.

Udvarhelyi Híradó, 1905. március 19.

Udvarhelyi Híradó, 1906. március 2. Udvarhelyi Híradó, 1906. június 10. Udvarhelyi Híradó, 1908. május 31. 


\section{A VILLAMOS ENERGIA HASZNÁLATÁNAK KEZDETEI GYERGYÓSZENTMIKLÓSON ÉS A GYERGYóI-MEDENCE TELEPÜLÉSEIN}

Már 1902-ben, Székelyföld városai és nagyobb települései villamosítása előtt Gyergyószentmiklós elsőként létesített villanyenergiát termelő villanytelepet. Ennek felszerelése két darab, egyenként 65 LE teljesítményű, Langfelder gyártmányú gőzgép, amelyeknek működéséhez a szükséges hőenergiát két darab, 1902-ben gyártott, 10 légkör nyomást fejlesztő, 50 m² fütőfelületű gőzkazán termelte. Mindkét kazán fa tüzelésű típus volt. A két gőzgép egy-egy elektromos áramfejlesztő generátort hajtott, amelyek akár a kazánok - szintén 1902-ben készültek. Ekkor már mindkét generátor háromfázisú, $50 \mathrm{~Hz}$ hálózati frekvenciájú, Siemens Halske gyártmányú volt. Ez azért említésre méltó, mert még a később létesített villanytelepek is egyenáramú generátorokkal dolgoztak. A gőzgépek laposszíj meghajtással csatlakoztak az áramfejlesztő generátorokhoz. A generátorok elektromos teljesítménye egyenként 40 kVA (kilovoltamper), összesen 80 kVA.

A kezdeti nehézségeket leküzdve a villanytelep egyre jobban, üzembiztosabban működött. A villamos energia iránti igény viszont egyre nőtt, a 80 kVA teljesítmény egyre inkább kevésnek bizonyult. Ezért már tíz év múlva, 1912-ben megtörténik az első teljesítménybővítés egy darab 165 LE teljesítményű, Schlick Nicholson gyártmányú gőzgép beszerelésével. Az új gőzgép egy 195 LE teljesítményű, háromfázisú, $50 \mathrm{~Hz}$ hálózati frekvenciájú, 210 volt üzemfeszültségű generátort hajtott. A gőzgép működtetéséhez szükséges gőzt egy 1912-ben gyártott Sie-

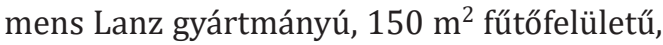
12 légkör nyomással üzemelő gőzkazán termelte. A fejlesztés eredményeként az összes termelhető villamosenergia $175 \mathrm{kVA}$, míg a meghajtó gőzgépek összteljesítménye 295 LE. A fogyasztókat légvezetékek csatlakoztatták az elosztó kapcsolótáblákhoz. A légvezetékek hossza 18 km volt, de már 200 m föld alatti kábelt is beszereltek.

Rövid idő múltán annyira nőtt a villamos energia iránti igény, hogy a 275 kVA teljesítmény kevésnek bizonyult. Ez azzal is magyarázható, hogy nem csak világításra

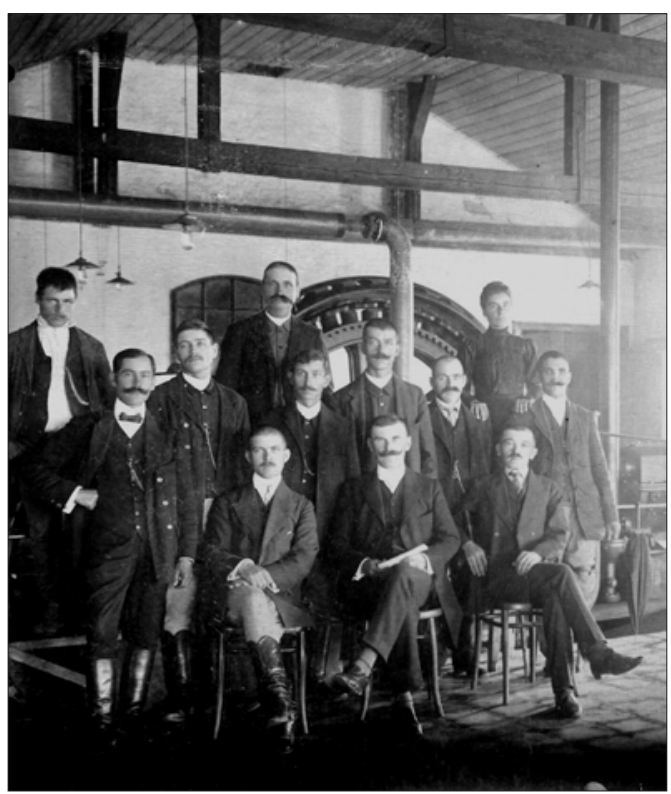

1. kép. A villanytelep alkalmazottai az 1930-as években 


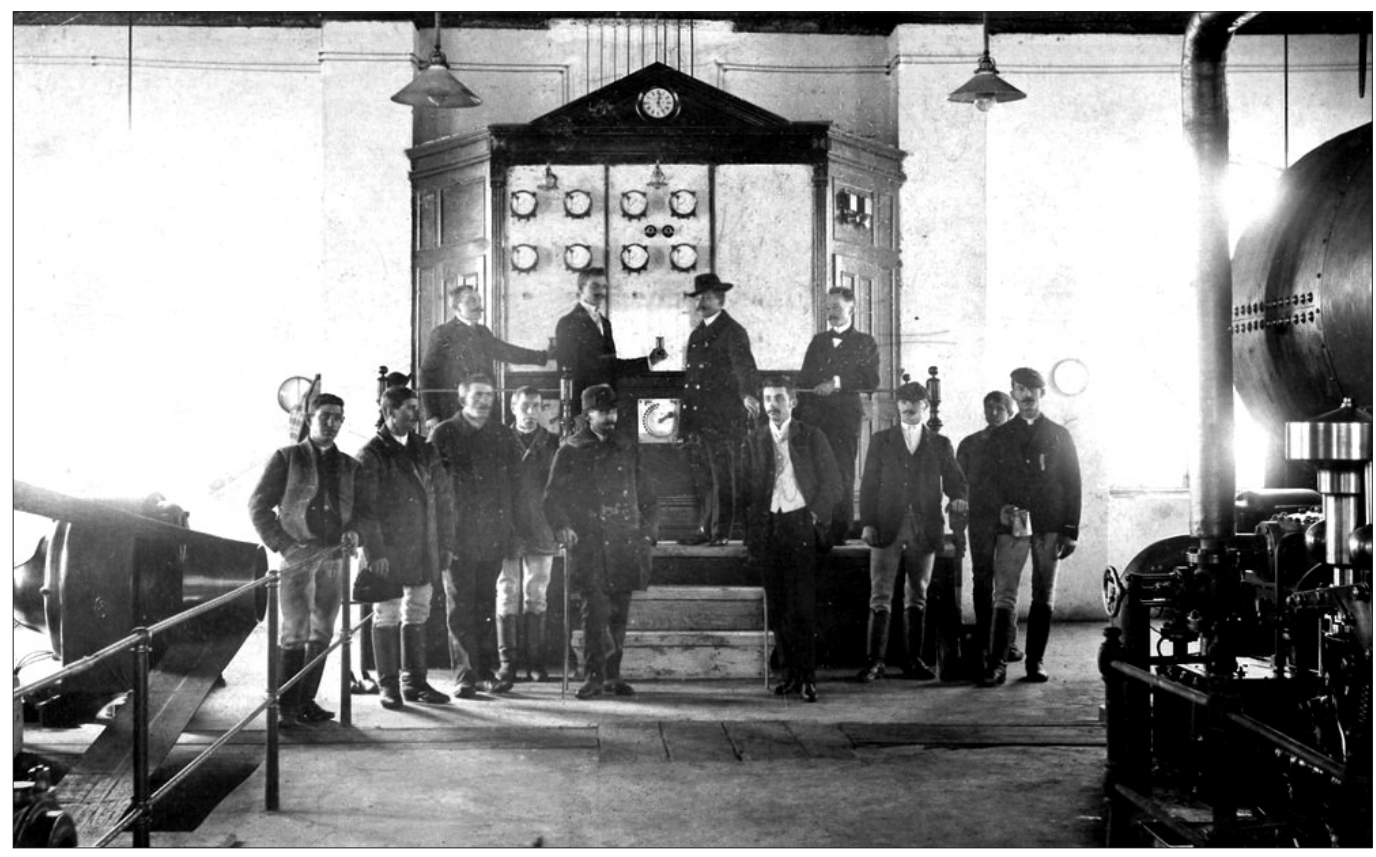

2. kép. A villanytelep alkalmazottai az 1930-as években

használták az elektromos energiát, ipari felhasználása is fokozatosan növekedett. Mindez megkövetelte a villanytelep termelőkapacitásának újabb növelését, a régi kapacitás felújítását.

1929-ben a tervbe vett megújítás a gőzkazánok cseréjéből, új generátorok beszerzéséből állt volna. Az is felmerült, hogy a gőzkazánokat, gőzgépeket dízelmotorokra cseréljék. Javaslat is született, hogy az energiatermelő kapacitást olyan mértékben növeljék, amely lehetővé teszi a Gyergyói-medence településeinek, a 9 községnek elektromos energiával való ellátását. A nagy reményű terveknek a közben bekövetkezett gazdasági válság vetett véget.

1939-ben egy új gondolat születik, amely a várostól 25 km-re fekvő Gyilkos-tó vízenergetikai hasznosítását tűzte ki célul, egy 500 LE teljesítményű vízerőmű felépítésével. Átdolgozták azokat a terveket, amelyeket már 1936-ban kidolgoztatott a város. Ekkor a teljes népességre és az egy főre eső éves fogyasztást az 1. táblázatban foglalt adatok szerint tervezték.

1. táblázat. A teljes népességre és az egy före esô éves fogyasztás 1939-ben

\begin{tabular}{|l|c|c|}
\hline Város vagy község & $\begin{array}{c}\text { Lakosok } \\
\text { száma }\end{array}$ & $\begin{array}{c}\text { Legnagyobb } \\
\text { terhelés } \\
\text { (kW) }\end{array}$ \\
\hline Gyergyószentmiklós & 11000 & 149 \\
\hline Remete & 8220 & 73 \\
\hline Ditró & 7842 & 70 \\
\hline Szárhegy & 4948 & 45 \\
\hline Gyergyóalfalu & 6743 & 60 \\
\hline Gyergyóújfalu & 3873 & 34 \\
\hline Csomafalva & 4706 & 42 \\
\hline Kilyénfalva & 1009 & 9 \\
\hline Tekerőpatak & 2939 & 26 \\
\hline Vasláb & 1351 & 12 \\
\hline Összesen & $\mathbf{5 2 6 7 1}$ & $\mathbf{5 2 0}$ \\
\hline
\end{tabular}


Az is felmerült, hogy a balánbányai rézmünek villamosenergiával való ellátása is megoldható lehetne a Gyilkos-tói vízerőmú megépítése kapcsán. A legnagyobb szükséges terhelés becslése annak figyelembevételével történt, hogy Gyergyószentmiklósnak abban az időben a legnagyobb fogyasztása $100 \mathrm{~kW}$ volt. „A helyi viszonyok alapján legtöbb 50\% szaporulat várható a jövőbeni kihasználásnál."
A tanulmány leszögezi, hogy nem lehet szó nagyobb növekedésről, mert „Gyergyószentmiklós városnak nincsen semmi lényegesebb fejlődési lehetősége félreeső földrajzi és kedvezőtlen gazdasági helyzete folytán".

A tervek megvalósításának a megváltozott geopolitikai helyzet, a második világháború vetett véget. 


\section{GYILKOS-Tó, BÉKÁS-SZOROS HIDROELEKTROMOS ERŐMŰ ÉPÍTÉSÉNEK TERVEI ÉS KUDARCAI}

A gyergyószentmiklósi villamos hálózat bővítése, valamint a Gyergyói-medence kilenc településének villamos energiával való ellátásának gondolata lehetett az 1902-ben beindult villanytelep 1929-re tervezett megújításának, fejlesztésének indítéka. Az 1902ben múködésbe lépett villanytelep 1912-ben már átesett egy jelentős bővítésen, aminek az eredményeképpen kapacitása 295 LE-s gőzgépből és 275 kVA összteljesítményű generátorokból tevődött össze. Az 1929-ben terveztetett újabb bővítés új gőzfejlesztő kazán beszerelésével egy időben új generátorok beszerzésének gondolatát is felvetette. Ebben az időben már gyakorlattá vált a dízelmotor energetikai alkalmazása. Ilyen háttérrel született a Gyergyói-medence kilenc települése villamosításának gondolata a már meglévő villanytelepre épülve. A terveknek sajnos véget vetett a bekövetkezett gazdasági válság. Ennek ellenére az általános villamosítás gondolata nem veszett el végleg Gyergyóban.

1935-ben a város vezetése egy újabb tervet dolgoztatott ki, ez alkalommal a várostól 26 km-re fekvő Gyilkos-tó környéki vízrendszer vízenergetikai lehetőségeinek hasznosításával. A tervezés indoklásában megfelelő hangsúlyt kapott a lendületes fejlődésnek indult Gyilkos-tó üdülőtelep villamosítása is. A tervek elkészítésére Dorin Pavel bukaresti mérnököt kérték fel, hogy kidolgozza az új energiaforrás hasznosítását. 1936. március 4-én a Közmunkaügyi Minisztérium Dorin Pavel tervét jóváhagyta, ami magában foglalta egy 500 lóerős hidroelektromos központ építését Gyilkos-tónál, a távvezeték építését Gyergyószentmiklósra és a kilenc községbe, valamint az elosztó transzformátorok telepítését ezekbe a helységekbe.

A gyergyószentmiklósi villanytelep a vízerőmű beindítása után továbbra is üzemben, működőképesen, tartalék energiaforrásként maradt volna. Gazdasági számításokat is készítettek, ezek szerint a vízerőmű 50 év alatt amortizálódot volna.

A város vezetése 1936-ban kisérletet tett a tervezett vízerőmű megépítésére koncessziós alapon. Megkereste az Italo-Belge társaságot, hogy ez vállalja el a Gyilkos-tói vízerőmű építését, és tegye meg ajánlatát ezzel kapcsolatosan. Megjegyezzük, hogy ez a társaság építette Brassó villanytelepét, tehát megfelelő gyakorlattal rendelkezett ilyen téren. A terveket a város eljuttatta $\mathrm{az}$ olasz-belga cég vezetőségének, ahonnan az igazgatóság két tagja mérnökeik kíséretében kiszállt a vízerőmű tervezett helyszínére, itt tanulmányozták a kivitelezés lehetőségét. A kiküldetést megismételték egy későbbi időpontban, ez alkalommal már vízhozammérő állomást is felállítottak a tó kifolyásánál. A Gyergyói-medence kilenc településén tanulmányozták a várható villamosenergia-fogyasztás távlatait, a kivitelezés lehetőségeit. Ezzel az ügy 1938 közepén lezárult, amikor is a brassói társaság közölte Gyergyószentmiklós vezetőségével, hogy nincs abban a helyzetben, hogy a vízerőmű megépítésével 
tovább is foglalkozhasson. Érthető döntés volt, ugyanis nemsokára kitört a második világháború.

A háború befejeztével ismét napirendre került, aktuálissá vált a vízerőmű megépítésének gondolata. Remélték, hogy „az olcsó elektromos energia biztos alapja és záloga lesz az egész gyergyói vidék iparosodásának" (László Antal 1940. november 26.).

1935-ben, amikor a Gyilkos-tó és környékének vízenergia-hasznosítási elképzelése megszületett, a város villamosítási foka alacsony szintü és kezdetleges volt. 1933-ban 10948 lakosra vonatkoztatott összfogyasztás $12 \mathrm{~kW}$ volt évente és személyenként, ami rendkívül alacsony fogyasztásnak számított. A környező falvak lakóinak száma: Remete 822, Ditró 7842, Szárhegy 4948, Alfalu 6763, Csomafalva 4706, Újfalú 3673, Kilyénfalva 1009, Tekerőpatak 2939 és Vasláb 1951, összesen 52671 fő Gyergyószentmiklóst is beleszámítva. Mindez indokolttá tette a meglévő villanytelep termelőkapacitásának növelését. Ekkor még egyetlen falu sem volt villamosított a Gyergyói-medencében.

A Gyilkos-tó turisztikai jelentőségét fokozza, állapítják meg a tanulmányok, hogy a tó vízgyűjtő kapacitása gyújtőtóként felhasználható a vízerőmú rendszerében. Az sem elhanyagolható, hogy a tó vízszintje alig változik, ezáltal mint energiaforrás gyakorlatilag állandó (1. kép).

Csupán érdekességként említjük meg, hogy a majdnem teljesen hiányzó villamos- energia-használat folytán a meglévő villanytelep termelése naponta néhány órán át állt, nyáron 5-14 óra között, télen 9-13 óra között. Gyergyószentmiklós legnagyobb terhelése ekkor 100 kW, jóllehet a villamosítás csak részleges. Becslések szerint, figyelembe véve a helyi viszonyokat, legtöbb 50\%-os növekedés volt várható a következő évtizedekben.

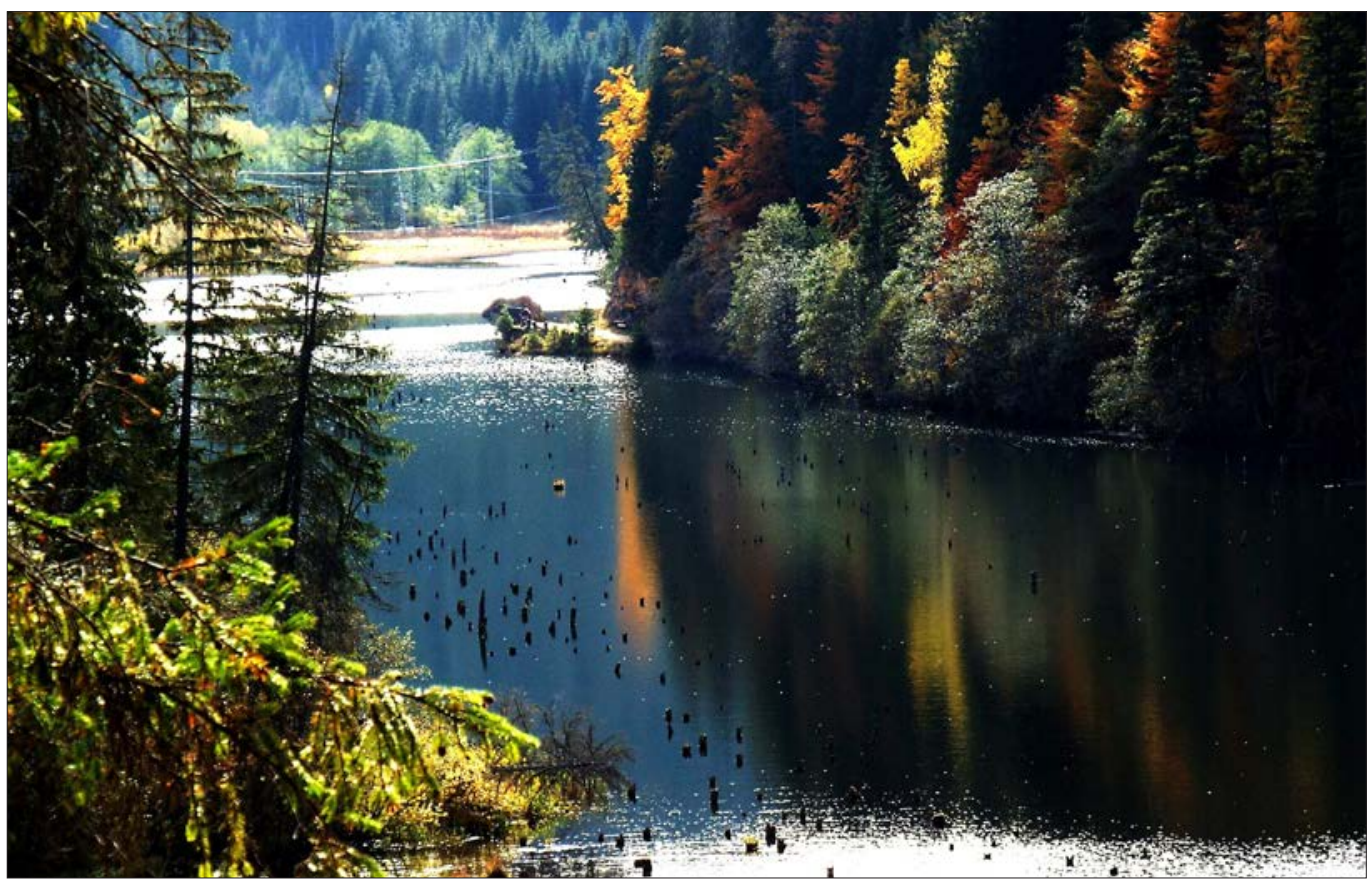

1. kép. A Gyilkos-tó ôsszel (Kémenes Árpád felvétele) 
A bevezető tanulmány azt is megállapítja: „nem lehet szó nagyobb emelkedésről, mert Gyergyószentmiklós városnak nincsen semmi lényegesebb fejlődési lehetôsége félreeső földrajzi és kedvezőtlen gazdasági helyzete folytán". (Mily tévedés!). Ezt figyelembe véve, összevetve az éves $12 \mathrm{~kW} /$ év/személy fogyasztással, és amit a községekben nem fognak elérni, a termelendő éves energiamenynyiség $12 \times 52$ 671= 630000 kWh/év kellet volna legyen.

Számítások szerint még ez az alacsony szintű fogyasztás is jelentős árbevételt eredményezett volna, ha megépül a vízi erőmű.

A városvezetés szakemberek bevonásával mérlegelte, hogy nem lenne-e hasznosabb a meglévő hőerőmű bővítése a vízi erőmű helyett. Végül azonban arra a következtetésre jutottak, hogy meghagyva tartalékként a meglévő hőerőművet fel kell építeni a vízi erőművet, mert ez lehetne a leggazdaságosabb, legelőnyösebb változat. Sokat nyomott a latban az, hogy a vízzel termelt energia olcsóbb, mert nincs megterhelve a tüzelőanyag költségeivel,... a jövőben a megnövekedett fogyasztás fatüzeléses rendszerrel nem lesz gazdaságos, ezért két dízel gépcsoport felállítása válik szükségessé. A nyersolaj ára azonban ezen a petróleumtermelő helyektől távol eső vidéken érezhetően magasabb, mint az ahhoz közelebb eső vidékeken.

Ezeket figyelembe véve a vízerőmüvet 500 LE teljesítményre tervezték, ami $330 \mathrm{kWh}$ elektromos energia lehetőséget biztosít. Ezt két Francis típusú turbina beszerelésével, üzemeltetésével érték volna el. A termelt energia 89\%-át vízi erőművel, 11\%-át hőerőművel nyerték volna. Az áramfejlesztés helyétől Gyergyószentmiklósra 15 kV-os távvezeték továbbította volna a fogyasztható elektromos energiát. A távvezeték hossza 21,4 km, ami követte volna az állami országút nyomvonalát, leszámítva a szerpentines szakaszokat. A $15 \mathrm{kV}-\mathrm{os}, 3 \times 16 \mathrm{~mm}^{2}$ keresztmetszetű távvezetéket vasbeton lábakra szerelt fenyőoszlopok tartották volna. A városi transzformátorállomás 15 000/6000 és 6000/2100 V lépcsőben szállította volna a felhasználók transzformátoraihoz az elektromos energiát, ahol 2100/220 V használati feszültségre csökkentették volna.

Mind a kilenc településen egy vagy két transzformátorállomást állítottak volna üzembe, a távolságok és a teljesítményszükségletek függvényében. Gyilkos-tó üdülőtelepet közvetlenül a vízi erőmű transzformátorállomásából látták volna el elektromos energiával.

Érdekességként említjük, hogy a vízi erőmű a tervek szerint $840 \mathrm{kWh} / \mathrm{nap}$ teljesítménynyel $0,30 \mathrm{~m}^{3} / \mathrm{sec}$ vízhozam felhasználásával működött volna. A $0,3 \mathrm{~m}^{3} / \mathrm{sec}$ vízhozam egy nap alatt a tó vizét $9160 \mathrm{~m}^{3}$ vízmennyiséggel apasztotta volna. Ezt a vízmennyiséget a tó felületére osztva, ami akkor $140670 \mathrm{~m}^{2}$ volt, 0,065 m tófelszín apadást jelentett, vagyis a tó felszíne 0,065 m-t fluktuált volna.

A $40 \mathrm{~km}^{2}$ vízgyújtő terület még a szárazságos években is biztosította volna az évi $0,877 \mathrm{~m}^{3} / \mathrm{sec}$ vízhozamot. Ez a vízhozam elegendő 500 LE erőkifejtésre, 353 KW generátorteljesítményre. Számítások szerint a gát 1 m-rel emelte volna a tó akkori vízszintjét.

A turbinához vezető vasbeton cső hosszát 1143,80 méterre, belső átmérőjét 900 mm-re tervezték. Az acél nyomócső 116,8 méter, belső átmérője $700 \mathrm{~mm}$ (1. ábra). Azt is figyelembe vették a kivitelezhetőségi tanulmány összeállításánál, hogy a vízgyüjtő terület 85\% a jól erdősített, ami kedvező feltételnek számított, mert ilyen helyeken nem alakulnak ki az esőzéseket követő vízmosások.

Több számítási módszer alkalmazásával, hasonlósági tanulmányokkal megállapították 
a több évre vonatkozó közép vízhozamot, hogy az eredmény a közép vízhozam esetében a lehető legnagyobb valószínûség határai közé kerüljön. A számítások az évi közép vízhozamra az 0,850 m³ $/ \mathrm{sec}$ értéket adták.

A vízmennyiség változhat évről évre a csapadékviszonyoktól függően. Ezt a változást 16 évre követve megállapították, hogy a legkisebb érték 620,5 liter/sec, a legnagyobb 1144 liter/sec volt. A hasznosítható vízhozam legnagyobb értékét 1000 liter/sec menynyiségre, míg az évi hasznosítható középértéket 700 liter/sec mennyiségre állapították meg (2. ábra).

Összehasonlító gazdasági számításokat is végeztek, hogy eldönthessék a fejlesztés irányát, vagyis hogy a meglévő hőerőmű további fejlesztésével vagy vízi erőmű építésével növeljék a villamosenergia-termelést Gyergyószentmiklóson. Megállapították, hogy hőerőtelep fejlesztéséről nem lehet szó, mert a teljesítmény kicsiny, és a szénhiány kedvezőtlen körülmény. Azt is leszögezték, hogy abban az esetben, ha a vízi erőmű nem valósulna meg, a dízel változat az egyedüli, amibe érdemes befektetni. A felszerelendő teljesítmény nagyságrendjét a meglévő teljesítmény hozzáadásával a vízi erőmű teljesítményéhez

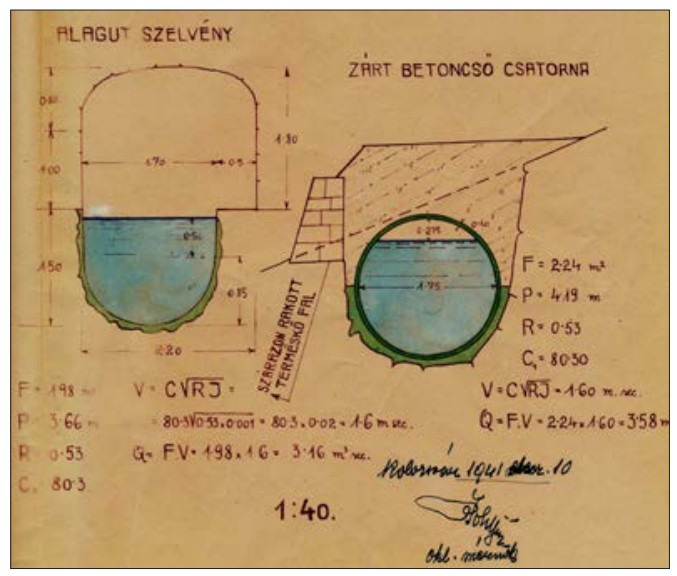

1. ábra. Felvízcsatorna részletrajzai
730 LE-t eredményezett volna. Ezt a teljesítményt három dízelegységgel, egyenként 250 LE-vel és közvetlen meghajtású generátorral tervezték.

A második világháború alatt mindenre lehetett gondolni, csupán vízi erőmű építésére nem, fóleg a Gyilkos-tónál. A terület ez alatt az idő alatt katonai múveletek színtere volt.

1941-ben ismét terítékre kerül a vízi erőmű megépítésének terve, azzal a különbséggel, hogy ekkor már rájöttek, az 500 LE (330 kW), ami abból adódott, hogy az éves csúcs 520 kW teljesítményből 190 kW a hőerőmű teljesítménye, így a $330 \mathrm{KW}$ teljesítményt vízenergiából kell majd előállítani. Figyelembe véve a szállítási, transzformálási veszteségeket $330 \mathrm{~kW} \times 1,36$, ez osztva 0,893 hatásfoktényezővel 502 LE turbinateljesítményt eredményez. A nagyobb biztonság megvalósításáért két generátort szereltek volna be, amelyekhez két Francis-turbina kapcsolódott volna.

A befektetés mértékéhez viszonyítva, figyelembe véve az aktuális gazdaságpolitikai távlatokat, kevésnek tartották a 330 kW teljesítményt. Ezért újabb változatokat fontolgattak. Egyrészt hasznosítani akarták a Kis-Békás vízenergetikai kapacitását, másrészt összesí-

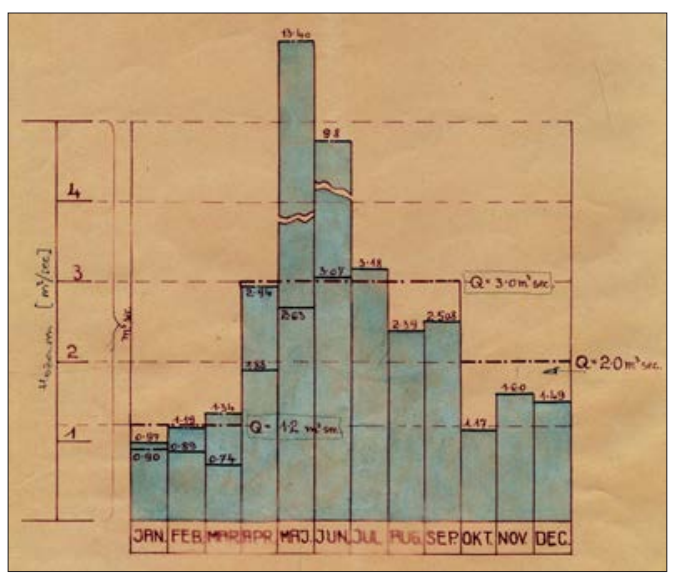

2. ábra. Víztömeg grafikon 
teni szerették volna a Békás és a Kis-Békás patakok energiatermelő adottságait.

Méréseket végeztek a Kis-Békás vízhozamviszonyainak megismerése végett, elkészítették a Kis-Békás tározómedencéjének részletes geodéziai felvételét.

Torkolati szakaszán a Kis-Békás patak meredek és magas sziklafalak között folyik. A torkolattól 1,2 km-re a vízfolyás völgye kitárul, a környező hegyek átlagosan 400 méter széles és mintegy $3 \mathrm{~km}$ hosszú, kis fenékesésü, így víztárózásra igen alkalmas medencét képeznek. E medence fölött a vízfolyás vadpatak jellegű. A völgy Szurdok nevű szorosában építették volna a zárógátat. A zárógát előtt a jobb oldalon lett volna a vízkivezetés. Innen a vizet alagút vezette volna a kiegyenlítő medencéig. Innen acél nyomócsövön a turbinatelephez. A turbinatelep, a Békás völgyében a két patak egybefolyásától kb. 800 méterre épült volna.
A Kis-Békás vízenergiájának hasznosítására két megoldás is megszületett. Az egyik változatnál csak a Kis-Békás vizét tárolták volna, a másik változat szerint a Kis-Békás és a Békás-patak vízenergiáját együttesen hasznosították volna úgy, hogy a Békás mellékpatakja, a Fügés-patak torkolata alatt létesített duzzasztómú közbeiktatásával alagúton átvezették volna a Békás és Fügés együttesét a Kis-Békás tározó medencéjébe. Ebben az esetben a Békás és Fügés együttesét két helyen tervezték hasznosítani: először a Kis-Békás tározójába való beömlése előtt, másodszor a Kis-Békás vizével együtt, a Békás-völgyi erőműnél (3. ábra).

A Kis-Békásnak 80,6 km² vízgyűjtő területe vehetô számításba, bár e terület csapadékban meglehetősen szegény, az átlagos évi csapadék mintegy $600-700 \mathrm{~mm} / \mathrm{m}^{2}$. Ezt az értéket nem mérésekkel állapították meg, hanem összehasonlítással, közeli csa-

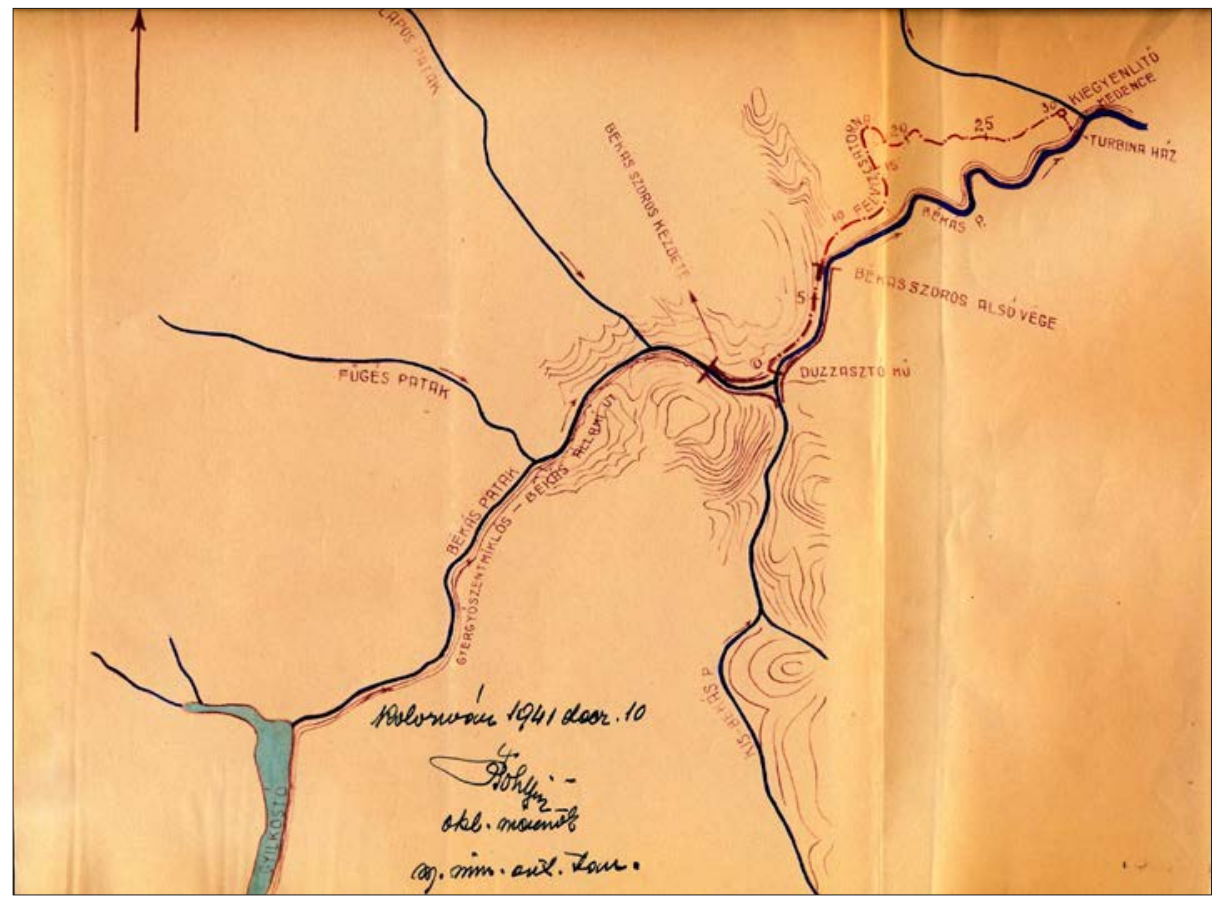

3. ábra. A Békás-patak és mellékpatakjai 
padékmérő állomások adataival (Balánbánya, Gyergyóbékás, Gyergyótölgyes, Gyimesbükk). Érdeksség ebben a témában, hogy az 1942-es év csapadékviszonyai megegyeztek az 1904. év csapadékával. Mindkét esztendő csapadékban szegényként szerepel a mérési adatok között.

A városvezetés 1941 októberétől tartott fenn rendszeres vízállásmérést a Békás-patakon, a Márk István villájánál található vízhozammérési szelvényben. Eddig a mérési pontig a Békás-patak vízgyújtőterülete 41,0 km².

A Fügéssel egyesült Békás- és Kis-Békás-patak együttes tizenkét hónapi vízmenynyisége összesen 47,0 millió $\mathrm{m}^{3}$ az ebből adódó közepes vízhozam pedig $1,50 \mathrm{~m}^{3} /$ sec. Biztonságból az üzemvízalagút áteresztő kapacitását túlméretezték úgy, hogy az esetenként $1,50 \mathrm{~m}^{3} / \mathrm{sec}$ vízhozamnál nagyobb árhullámot is átvezesse a gyűjtőmedencébe túlterhelésmentesen.

A hidrológiai tanulmánnyal párhuzamosan a geológiai viszonyokat is tanulmányozták 1942 nyarán és őszén, a Földtani Intézet közreműködésével. Megállapítást nyert, hogy az alapkőzet ugyan mészkő, ezt azonban a medence majdnem egész kiterjedésében olyan vastag pala, illetve homokkő fedőrétegek borítják, hogy a víz elszivárgásától nem kel tartani. Ez a fedőréteg csupán a völgyelzárásra kiszemelt szorulat közelében vékonyodik el annyira, hogy ott esetleg kisebb területen cementbesajtolásra lesz szükség.

A gát végleges helyét a további, részletes kutatások eredményétől tették függővé, anynyit viszont megemlítettek, hogy a szorulat alkalmas lehet íves gát megépítésére. A gátat a mintegy 250 méter hosszú szoros felső végében célszerű elhelyezni.

Az íves gátnál az erőhatást oldalt, a vállak támasztópontjaiban veszi át a sziklafal, ugyanakkor a hőmérséklet-ingadozás okozta tágulás lehetősége is megoldott.

A völgyzárógát építésére megközelítőleg 2310 m3 faltérfogat volt szükséges. A tározótér befogadó képessége 13 millió köbmétert tett ki. Ebből következően 1 köbméter faltérfogatra 5628 köbméter tározótérfogat jutott.

A víznyomásból származó legnagyobb nyomófeszültség $12,5 \mathrm{~kg} / \mathrm{cm}^{2}$. A méretezés magában foglalta a jégnyomásból származó feltételezhetően kialakuló legnagyobb igénybevételt is. A jég vastagságát egy méterrel számolták és megállapították, hogy ezen a tengerszint feletti magasságon, amit 855,00 méternek vettek, a számított eredőfeszültség nem haladja meg a $12,5 \mathrm{~kg} / \mathrm{cm}^{2}$ igénybevételt.

Az előzetes, kivitelezhetőségi tervekben a tározó vízének az erőműhöz való vezetése módosított változatára is kitértek. Ezek szerint a gáttest előtt, a jobb oldalon 826,00 tengerszinti fenékmagasságból kiindulva mintegy 2 km hosszú üzemvízalagút vezetett volna, nyomás alatt a kiegyenlítő medencébe. Ezen a szakaszon egy ellenőrző aknát is létesítettek volna. A kiegyenlítő medencéből meredek esésű acél nyomócsövön jutott volna el a víz a Békás-völgyi turbinatelep gépegységeibe. Így a legnagyobb természetes esés, 160 méter, keletkezett volna.

Ha a másik változatot részesítették volna előnyben, a Békás vizét a magasságkülönbségeket kihasználva először a Kis-Békás tározó medencéjébe vezették volna mintegy 1 km hosszú üzemvízalagúton át. Innen a tározó mellékvölgyében létesített kiegyenlítő medencéből acél nyomócsövön, 36 méter természetes eséssel vezették volna a vizet a turbinatelephez. Ebből kitűnik, hogy minden változatot előterjesztettek, hogy a szakemberek mérlegeljék ezeket, és a leggazdaságosabb változat megépítése mellett dönthessenek (2. kép). 
A Kis-Békás patak vízerejének hasznosítása révén mindkét változat esetében „olyan nagy energiamennyiség termelhető, amekkora Gyergyószentmiklós város és a környező községek villamos árammal való ellátását lehetővé teszi" (Kanizsai Alajos D.C. 627.8.).

A tervek kivitelezésébe ismét beleszólt egy újabb, ezúttal a második világháború és annak következményei. Évek múltán bebizonyosodott, hogy a Gyilkos-tó és környékének vízenergetikai lehetőségei csak töredékét fedezték volna annak a szükségletnek, amelyet a vidék fejlődése megkövetelt.

\section{Felhasznált irodalom}

Kanizsai Alajos: A Kis Békás patak vízerejének hasznosítása. D.C. 627. 8.

László Antal: Átirat. Gyergyószentmiklós, 1941. december 13.

László Antal: Jelentés Gyergyószentmiklós és vidéke elektromos energiával való ellátásáról. Gyergyószentmiklós Megyei Város Mérnöki Hivatala. Gyergyószentmiklós, 1940. november 26.

Márton László: Változatok a Gyilkos-tó vízrendszerének hasznosításáról. Hargita, 1981. április 11.

Márton László: Változatok a Gyilkos-tó vízrendszerének hasznosításáról. In: Korunk évkönyv 1989. 39-42.

Pavel, Dorin: Memoriu asupra centralei hid-

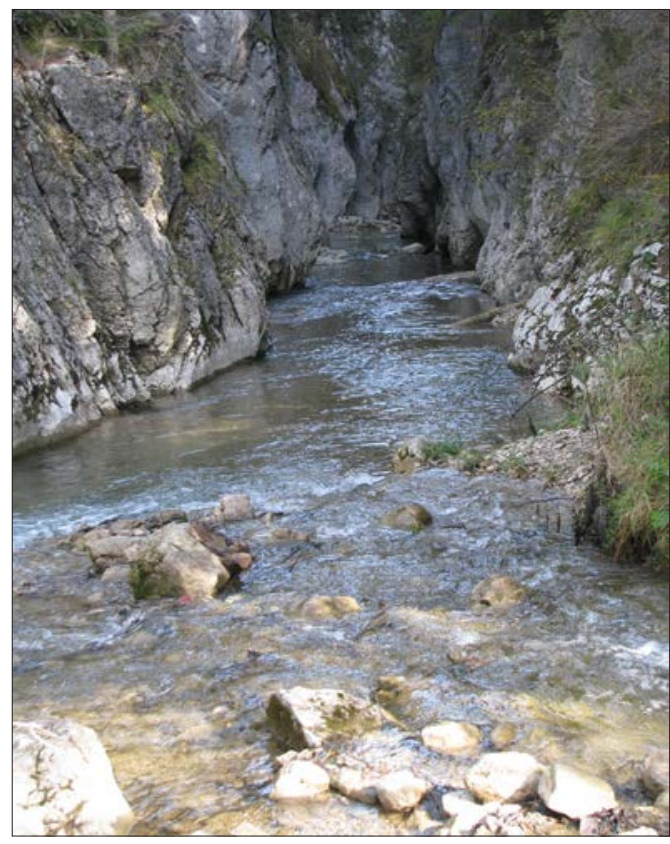

2. kép. A Kis-Békás patak, szurdok (Kémenes Árpád felvétele)

raulice Ghilcoş în legătură cu electrificarea oraşului Gheorgheni şi a comunelor invecinate. Bucureşti, 1935.

Pohl Béla: Gyilkostói vízierôtelep helyesbített vízmütani és gazdasági számításai. Kolozsvár, 1942. augusztus 20.

Vofkori György: Gyergyószentmiklós. Várostörténet képekben. Gyilkos-tó, Békás-szoros. Polis Kiadó, Kolozsvár, 2004. 136, 137, 216-243. 


\section{KOMMANDÓ VILLAMOSÍTÁSÁNAK TÖRTÉNETE}

A 19. század végén Háromszéken a fafeldolgozást csak házi mesterségként gyakorolták, bár Kommandón és környékén óriási őserdők álltak hasznosítás nélkül. Miután a vasút elérte Brassót, több iparmágnás szerette volna a környező erdőket kitermelni, de lehetetlen vállalkozásnak tűnt, ezért a kitermelés váratott magára. 1886-ban Horn Dávid felvidéki faiparos és üzletember megvásárolta Zathureczki Gyulától 14582 kataszteri hold erdő kitermelésének jogát, és ezzel megvetette a faipar alapjait itt a hegyek tetején, az egykori Háromszék vármegyében, a megye legmagasabban fekvő településén, Kommandón. Ekkor itt a kor legmodernebb technikáját alkalmazták, amiből a villamosenergiafejlesztés és hasznosítása sem hiányozhatott. Levéltári adatok, hírlapok és szakirodalmi feljegyzések igazolják, hogy az akkori Háromszék vármegyében elsőként alkalmazták a villamos energiát, amit helyben állították elő. Kommandótól 6 km-re, 1888. október 17-én, délelőtt 10 órakor Horn Dávid tulajdonos jeladására elindult a 8 keretfürészes fürészgyár 900 munkással, akik Gyulafalván laktak. Számos tiszti (tisztviselőház) és mun-

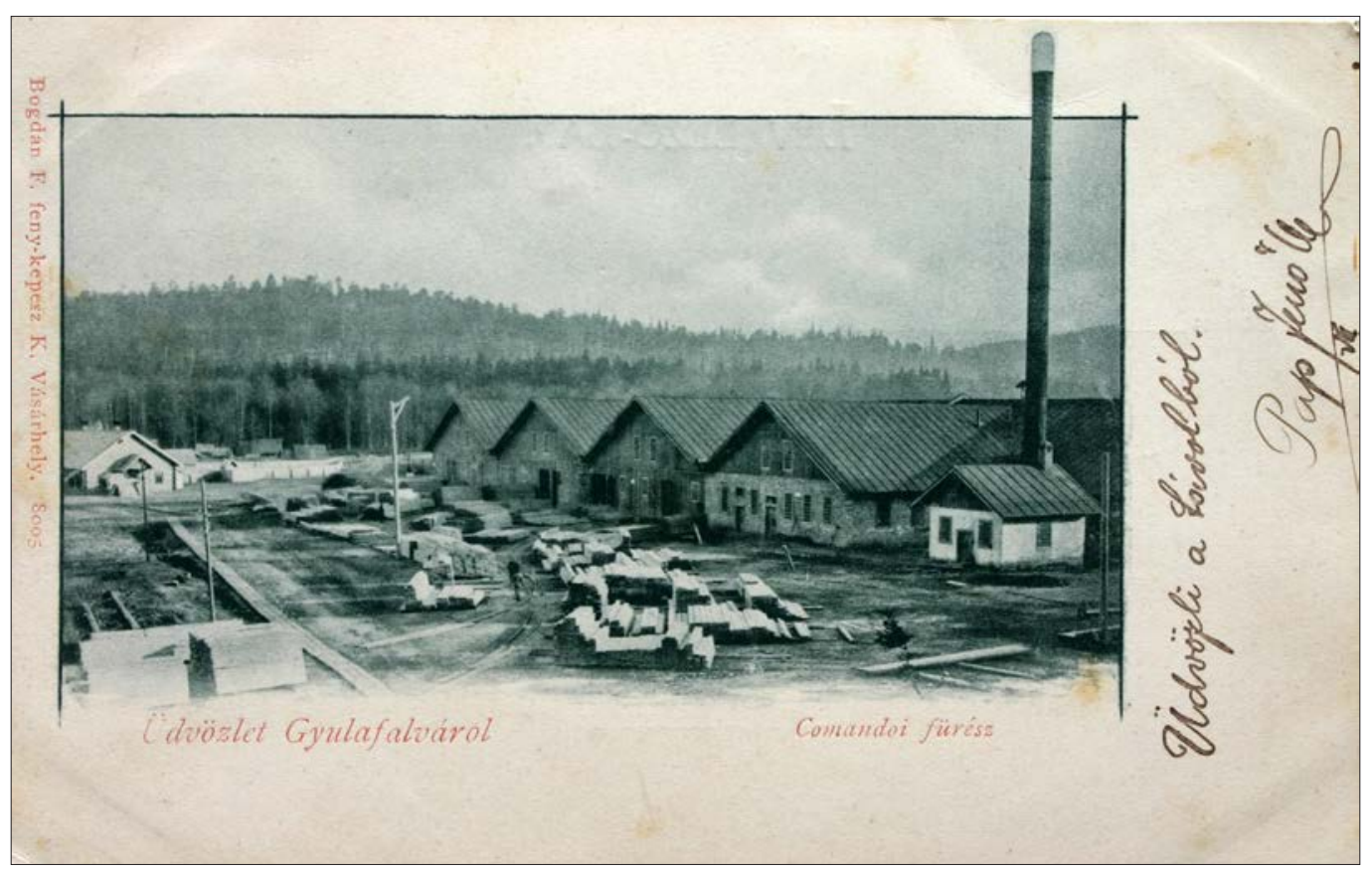

1. kép. A kommandói gyár 1899-ből 
káslakás adott otthont a faiparban dolgozó családoknak. A fürészgyárat vasúti sínekkel, úgynevezett lóvonatú vaspályákkal kötötték össze a vágterekkel, ahol lovak vontatták a kocsikat. Horn Dávid valamennyi elképzeléshez az ötletet Magyarországról hozta, hiszen ott már az 1800-as évek közepén léteztek hasonló vaspályák (Pótsa József 1899. 287.). Mindenből talán a legszebb és legegyedibb az volt, hogy a gyár elindulásával 1888. október 17-én kigyúlt a villanyfény is Kommandón. Az egyszerű emberek a földre borultak, és keresztet vetettek, mert azt hitték, hogy mennyei csoda történt. Valóban csoda történt, de nem égi csoda, hanem egy haladó eszméjű vállalkozó csodája, aki elérte azt, hogy országos szinten, Temesvár után Gyulafalván másodiknak, majd 1889-ben Kommandón gyúljon ki a villanyfény a közvilágításban.

Temesváron 1884-ben gyúlt ki először a villanyfény, ami akkoriban nem Erdély területéhez tartozott, tehát erdélyi szinten Gyulafalván gyúlt ki elsőnek a villanyfény, hiszen még Brassóban is gázzal világítottak. Dr. Rosta István azt írja, hogy Temesvár villamosítása volt a múlt század végén az első kiemelkedő technikatörténeti esemény. 1884-ben az angol-amerikai Brush Co. szállított oda hagyományos egyenáramú világítási rendszert.

Erdélyben 1888-ban megjelentek az első Ganz rendszerű váltakozó áramú berendezések, amelyeket közcélú világításra kezdtek üzemeltetni. A gőzgépek - nagy testű gépek voltak, amelyeknek a szállítása darabokban történt - összerakásához, kezeléséhez fejlett technikai tudás szükségeltetett (Rosta István szerk. 1995. 124.).

Ezzel az alkotásával diadalt aratott Horn Dávid, meghódította az őserdőt, és megmutatta azt, hogy az erdei fenyő igazi arannyá válik, ha megfelelő kezekbe kerül.
A gyulafalvi fúrésztelepet 1888. október 17-én helyezték üzembe, de az avatóünnepségre csak 1889. január 15-én került sor. Az avatóünnepségre küldött meghívóban ez olvasható:

\section{„Meghívó}

Papolc község határában levő Zathureczky Gyula úr és társai-féle erdőben létesített (Gyulafalvi) gözfürész gyártelepemnek 1889 évi jan. hó 13-án (vasárnap) du. 5 órakor a helyszínen leendő ünnepélyes felavatásához van szerencsém uraságodat meghívni, kérvén nagyra becsült megjelenésével az ünnepélyt megtisztelni.

Kiváló tisztelettel: Horn Dávid"

A vállalkozó nyilván büszke volt a sikerére, és ezt meg akarta osztani másokkal is. Az avatóünnepségre meghívott minden jelentős személyt, beleértve a sepsiszentgyörgyi Székely Nemzet lapszerkesztőjét is. 1889. január 15-én megjelent a tudósítás, amelyben többek között ez olvasható:

\section{„Az ipartelep felavatása Gyulafalván}

A gőzfürészgyár, mely Zathureczky Gyula tulajdonát képező tizenkétezer holdnyi erdőséget van hivatva 25 évi kihasználási idő tartamán belül feldolgozni, alig néhány hónap alatt bámulatos gyorsasággal épült fel. Papolc községtôl 22 km-re fekszik, honnan egy a tulajdonos által jól járható közlekedési út vezet a telephez. Azon esetben, ha tervbe vett háromszéki vasút felépül, Horn Dávid úr egy pályát szándékozik építeni, mely Gyulától kiindulva Kovászna felé venné irányát, hol egy nagy raktár lesz berendezve az ide szállítandó anyagok számára. A telepre megérkezve újabb és kedves meglepetés várakozott a vendégekre. A bejáratnál lampionokkal s zöld fagallyakkal díszített diadalkapu volt felállítva: *Isten hozott* és *Éljen az ipar*. A megnyitón jelen voltak: Pótsa Józseffőispán, Szentkereszti 
Béla országgyúlési képviselő, Szentiványi Miklós megyei föjegyzö, Zathureczky Gyula földbirtokos és mások. A villanyvilágítás fénye mellett megszemlélték a Nedoma építömester által ügyesen és szépen felállított épületeket, a krompachi vasgyárból szállított és ugyanott készített gépeket, a Ganz féle villanygépeket, a múhelyeket, a raktárat és a kazánházat. Mindenki az emberi munka bámulatos alkotó erején csodálkozott, hogy e lakatlan, elhagyott erdöségben oly bámulatos gyorsasággal, egy ezreknek kenyeret adó óriási iparvállalat létesült." (Székely Nemzet 1889/6. 3.)

A gőzgép és az áramfejlesztő generátor a fatelepek legfontosabb részei voltak. Kommandón és környékén a faipar fénykorában három fürészüzem létesült: József-fürész (Gyulafalva), Gábor-fürész (Kommandó)
Brackó-Musa-Ghermani-fürész (Musa). Minden egyes fatelepnek volt gőzgépe és áramfejlesztő generátora. A keretfürészeket gőzerővel működtették. A gőzgépek transzmissziós szíjakkal voltak ellátva, a gyártelepeken alagútrendszert építettek ki, és szíjak segítségével vezették a gőzerőt a gépekhez. A kommandói adatközlők még napjainkban is emlékeznek arra, hogy az alagutakat akkor tömték be, amikor a régi gyártelep helyére tömbházakat építettek az 1980-as évek elején. Az alábbiakban olvassuk el Sümegh Ignác 1898-as leírását az Erdélyi Erdőipar Rt. (Horn Dávid fatelepei) gépeiről:

„Gábor-fürész (Kommandó): A hajtőerôt szolgáltatja egy 250 lóerejú magas nyomású vasmüvel ellátott (Meyer-féle) iker-gőzgép a Nicholsontól. Gốzfejlesztésre szolgál 4 henger-

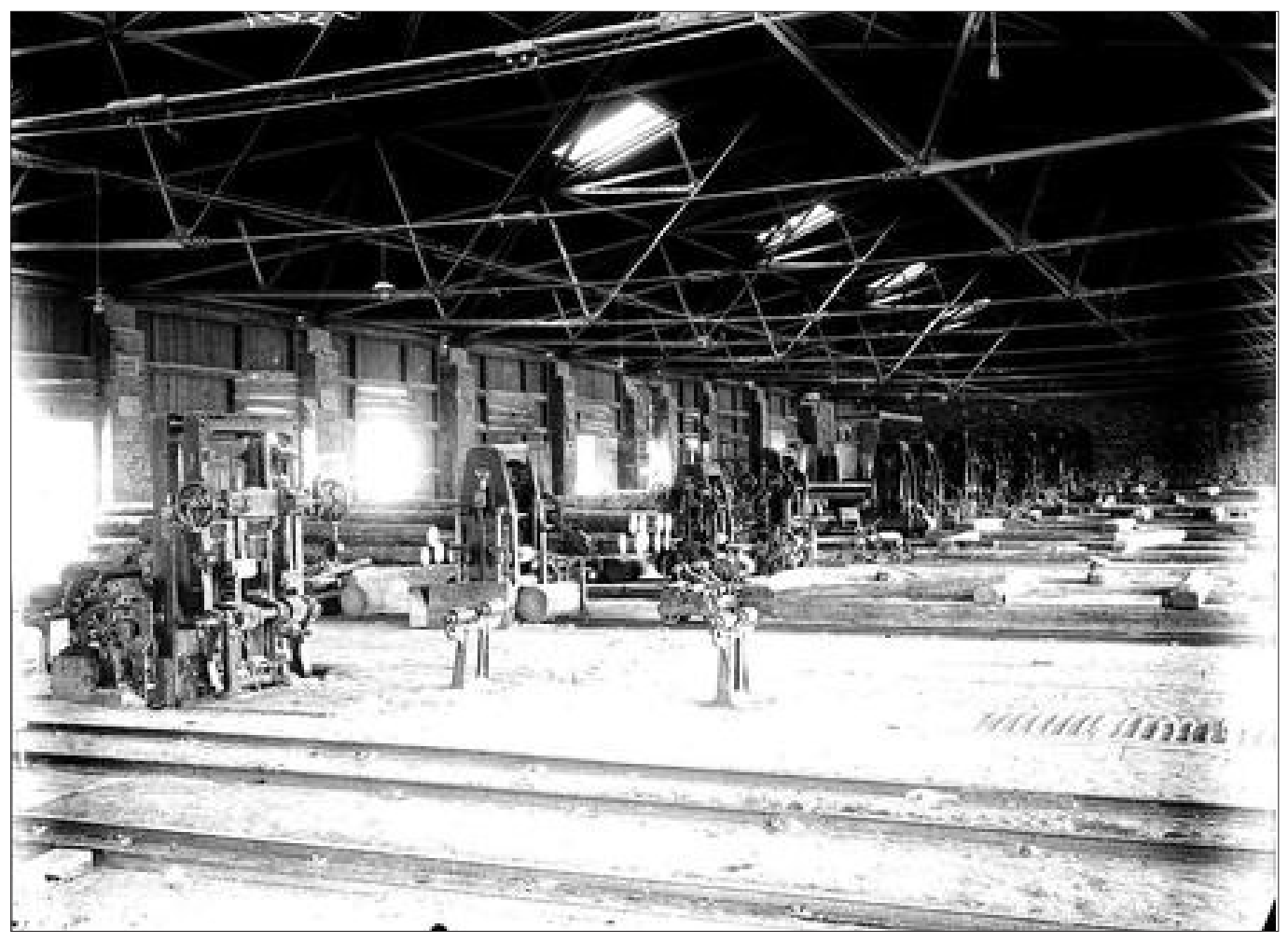

2. kép. Kommandoi gatterszín 1924-ben (Adler Leopold felvétele) 
kazán két előmelegítôvel $50 \mathrm{~m}^{2}$ fütôfelülettel a Nicholsontól. Villamos világításra szolgál egy 9 lóerejü gőzgép (Tangens-féle szabadalom), hajtja egy delta jegyú Ganz gyárban készült 100 amper és 110 volt feszültségü dinamógép. Előbbi tartalékul, utóbbi erőátvitelre szolgál.

József-fúrész (Gyulafalva): Gépházában van egy 150 lóerejü gőzgép fogaskerék átvitellel, egy szivattyú, ezenkívül van lakatos mühely egy esztergával és fúrógéppel.

Brackó-Musa-Ghermani nevü fürész berendezései: 250 lóerejú gőzgép Nicholsontól, 3 gőzkazán." (Székely Nemzet 1898.)

Az évek során változtak a gépek, a gyárak többször is leégtek, és köztudottan a történelem fordulatai, a háborúk, a határosztások mindenkor befolyásolták a vasútüzem sorsát. Tehát valószínű, hogy a későbbiekben is léteztek a fatelepeken hasonló gőzkazánok, generátorok, hiszen a kordokumentumok szerint 36 keretfúrész múködött Kommandó fénykorában, vagyis 1924-ben, de források hiányában bővebb információt nem tudunk. Ugyanúgy arról sem tudunk, hogy a „Bükk-gyárban” milyen gépek voltak. A bükkfát feldolgozó gyár a második világháború után a kommandói központi gyár alegységeként saját kapcsolótáblával rendelkezett, mert a villanyáramot a fenyőt feldolgozó, puhafateleptől kapta.

Kommandón a gyár irányában volt a gépház, itt helyezték el a gőzgépet, az áramfejlesztő generátorokat, a kapcsolótáblákat, amelyek az 1889-1980 közötti időszakban a magasfeszültségi hálózat megjelenéséig az áramot szolgáltatták mind a gyáraknak, mint a településnek. A generátorok a kezdetektől a közvilágítást is ellátták, de háborús időkben a keretfúrészeket is villanyárammal működtették. Volt olyan időszak, amikor a faluban nem volt áram, mert a gőzgép teljesítménye nem volt elég a település és a gyár szükségleteinek ellátásához. A hangsúly mindig a vasútüzem megvilágítása volt. Az adatközlők emlékei szerint volt egy nagyméretű kapcsolótábla, amelyet a gépészek kezeltek. Kötelességük volt a villanyhálózat be- és kikapcsolása. Az utcákon villanyoszlopok voltak, amelyeken szintén kapcsolókkal indították a közvilágítást. Az utcai világítás ki- és bekapcsolása az éjjeliőrök kötelessége volt, de az éjjeliőrök óráit szintén a villanyoszlopokon található kulcs segítségével húzták fel, így igazolták szolgálatuk teljesítését.

Az alábbiakban Haszmann Pál visszaemlékezéséből idézünk egy rövid részletet:

„Mivel állandó éjszakai szolgálat volt, egy szoba az éjjeliöröknek volt fenntartva. Ezek vezetöje Török bácsi volt. Az öröknek börtokban tartott óra volt a nyakukba akasztva. Az óra úgy volt megszerkesztve, hogy abba egy papírszalagot helyeztek bele. A telep területén oszlopok voltak felállítva azokon egy bádogdobozban kulcs. Az órát megfelelő időben csak azzal a kulccsal lehetett felhúzni, ami a szalagra rápontozta az idôt. E rendszerrel ellenőrizte az éjjeliőröket, hogy teljesítették-e a kötelességüket." (Haszmann Pál 1971.)

Az első, vagyis a Horn Dávid által hozatott csepeli gőzgép, amely 1957-ig múködött, kétkazános Ganz típusú hajógép volt. Ezt a gépet 1958-ban elvitték Piteşti-re, s ezután az áramot két August 23 és egy Škoda típusú dízelgenerátor biztosította. A mostani gőzgéproncs elődei: 1958-ban egy 70 lóerős Pojoriţa, 1961-ben egy 120 lóerős gőzgép Câmpulung Moldovenescről, amely 1967-ig működött, majd ócskavasba került. Az utolsó gőzgép, mely 1967-ben kezdte meg a múködését, egy kazános fürészkorpa üzemeltetésű volt. A generátor, amit 450 lóerővel hajtott meg, utolsó kezelője a nyugdíjas Zonda Jenő gépész volt. A gőzgép 1999-ig működött, ekkor eltörött a forgattyús tengelye, a javí- 
tásból már nem tért vissza Kommandóra. Valószínúleg ócskavasként végezte be pályafutását. A gyár órára pontosan 110 évig müködött (1889. október 17. 10 órától - 1999. október 17. 10 óráig).

A magasfeszültségű hálózat kiterjesztése után Kommandón egy ideig még élt a gőzgép. Kazánjában égették a hulladék fát és a fürészkorpát, de az áramfejlesztő generátor lendkereke csak akkor lendült működésbe, ha meghibásodott a magasfeszültségú hálózat, ráesett egy fa a vezetékre, vagy az erős szél összeverte a huzalokat, és rövidzárlat keletkezett. Ilyen esetben a helyi generátor csak a gyárat látta el villamos energiával. Megöregedett alkatrészei gyakran javításra szorultak, majd 1999. október 17-én 10 órakor a gyárral együtt végkép leállt. A fölöslegessé vált gépeket széthordták, napjainkban csak töredéke van meg az áramfejlesztő generátornak. A háromfázisos generátor a gyár leállásakor még múködőképes állapotban volt, de a fémtolvajok a későbbiekben ezt sem kímélték, akárcsak a kapcsolótáblát.
Minden mozgathatót elvittek, széthordtak az élelmes fémgyűjtők. A régi, muzeális értékű WOLF típusú generátor 2006 márciusában (a gyár rövid üzemeltetésekor) még ott volt a pincében. Mostanra teljesen tönkrement az utolsó gőzgép is, akárcsak az áramfejlesztő generátor. Csupán roncsaik hevertek a félig összeomlott gépházban. 2012-2013-ban a fémtolvajok nemcsak a generátor roncsait, de még a múhely vasajtaját is elvitték. A két darab öttonnás öntvénykerék, vagyis a javításba vitt forgattyús tengely lendkerekei ott hevertek Kovásznán, a Perdi gyár udvarán. Miután ez a gyár is leégett, a lendkerekeknek is örökre nyoma veszett, bizonyára ezek is ócskavasként fejezték be életüket.

\section{Vízerőmü-tervezet}

A második bécsi döntés után Kommandó erdőterületeinek nagy része román területre került, ezért újabb módosításokat kellett figyelembe venni. Például vissza akarták állítani a katonai bázist, a turizmus lehetőségeit is latolgatták. A magyar állam a település

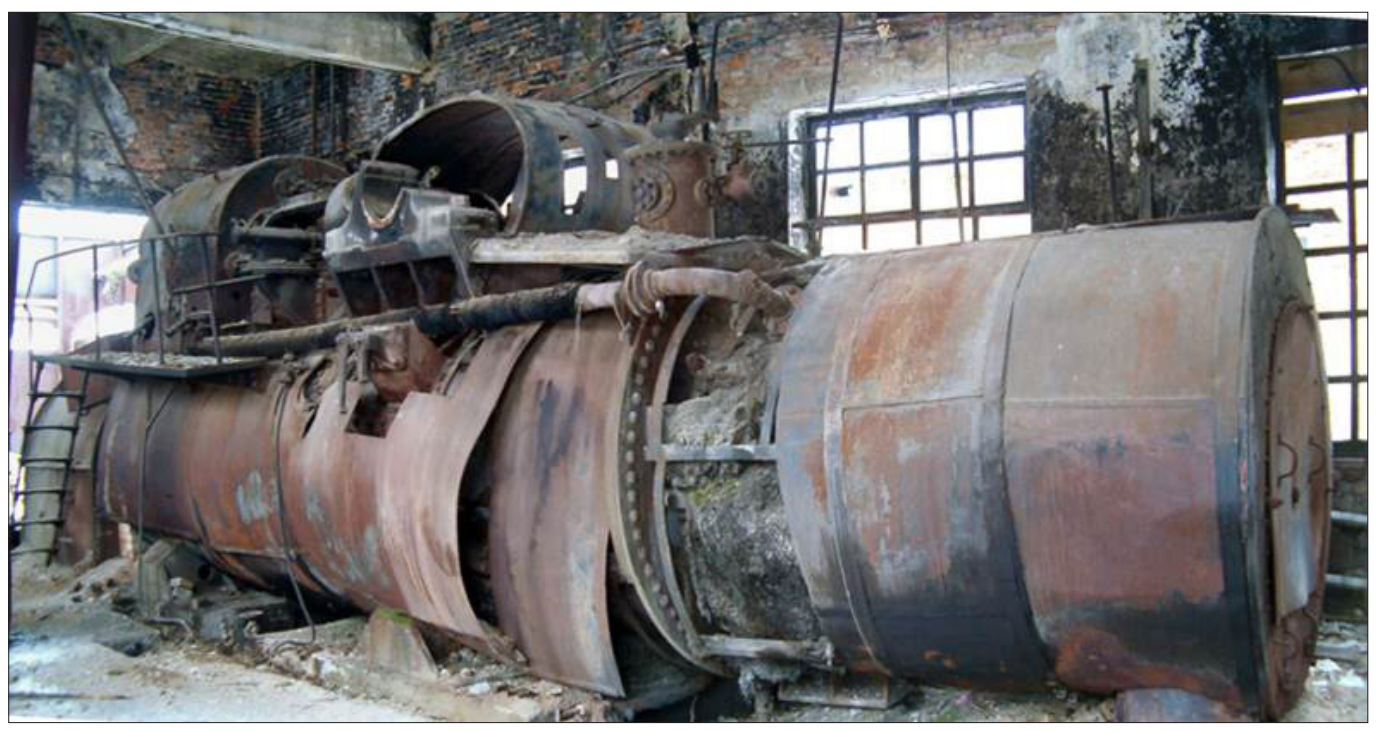

3. kép. Kommando. A gőzgép roncsai napjainkban 
másik természeti kincsét, a Bászka vizét akarta felhasználni, 1942-ben készült egy tervezet vízi erőmű építésére.

A Nagy-Bászka a háromszéki lapály fölött 550 méter magasságban folyik. Kedvező földtani helyzete révén a vízválasztót rövid alagúttal át lehetne törni, ami által a Nagy-Bászka vize a háromszéki lapály felé ömlene. Szakemberek szerint a víznek ide irányítása nem természetellenes, mert a környék vizei, amint megállapították, valamikor a háromszéki síkság felé folytak. Közben azonban földtani hátráltató erők támadtak, és a víz folyását Románia felé irányították. Tervek szerint a Nagy-Bászka völgye az Ölves- és Hagymás-patakok torkolata alatt gáttal elzárható. A mindenfelől körülzárt völgyben ezáltal tó keletkeznék, amely nemcsak a környékről jelentékeny tömegben lezuhogó vizekből, de a csapadékokból is meggazdagodnék. A tárolómedencébe 5 millió köbméter víznek kell beleférnie. Az ilyenfajta erőművek létesítésénél igen fontos az esés kérdése is. A lapály peremén elhelyezkedő előhegyek magassága nem éri el a Nagy-Bászka völgyének magasságát, ezt a rendelkezésre álló esését ilyenformán jól ki lehet használni, éspedig két lépcső beállításával. Egyik a kovásznai siklónál, a másik a Kapocs-hegynél lenne. Az előbbinél 400 m esés, a másodiknál $100 \mathrm{~m}$ állna rendelkezésre. Az erőműtelep évi erőtermelése 30 millió lóerő lenne. Háromszék falvai nagy részét villannyal lehetne ellátni a Nagy-Bászka vízerejének a felhasználásával, és ezáltal a jelenleg leállott üzemmel dolgozó kommandói munkások megélhetésre találnának.
A helyi adottságok olyanok, hogy az építésnél különösebb nehézségek nem merülnének fel. Az alapkövezet kárpáti homokkő, ez gátépítésre és víztárolásra alkalmas. A kiépítendő vízművek az iparvasút közelében lennének, tehát az anyag elszállítása is olcsón és könynyen történhetik. A vízmű kiépítése előzetes és hozzávetőleges számítás szerint 5 millió pengő́t tesz ki. A nagyvonalú terv természetesen csak a háború után valósulhat meg. De az erőműteleppel nemcsak Háromszék falvainak a villamosítását lehetne megoldani, hanem üzemben tartásánál is hasznos lehetne (Szabó Mária 2004. 62.).

\section{Felhasznált irodalom}

Haszmann Pál: Kommandó. Megyei Tükör 1971.

Látó Anna: Honvágyam hiteles története. Kriterion Könyvkiadó, Bukarest, 1981.

Pótsa József (szerk.): Ezeréves Háromszék Vármegye. Emlékkönyv Magyarország fennállása ünnepére. Jókai nyomda, Budapest, 1889.

Rosta István (szerk.): Fejezetek a magyar technika történetéből. Nemzeti tankönyvkiadó, Budapest, 1995.

Szabó Mária: Kommandó monográfia. T3 kiadó, Sepsiszentgyörgy, 2004.

Székely Nemzet, VII. évf. 4. szám, 1898 jan. 6. Székely Nemzet, VII. évf. 6. szám, 1889 jan.15. Székely Nemzet, XVI. évf. 128. szám, 1898.

Székely Nép, LX. évf. 74. szám, 1942. április 1.

\section{Adatközlők}

Farkas Tibor (1952-2017) Kommandó

Szabó Dávid (1956) Kommandó

Zonda Jenő (1928-2010) Kommandó 